$$
\text { DOE/PC/91159-.T/ }
$$

\title{
DEVELOPMENT OF A REBURNING BOILER PROCESS MODEL
}

DOE/PC/91159--T1

DE92 013027

First Quarterly Progress Report

October 1, 1991 through December 31, 1991

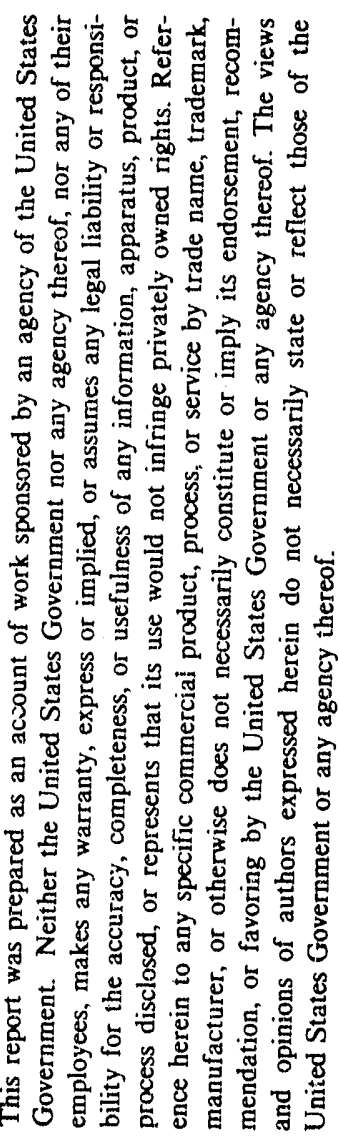

\author{
Prepared for: \\ U.S. Department of Energy \\ Pittsburgh Energy Technology Center \\ DOE Contract No. DE-FG22-91PC91159
}

Prepared by:

K.T. Wu

Energy and Environmental Research Corporation 18 Mason

Irvine, California 92718

January 30, 1992

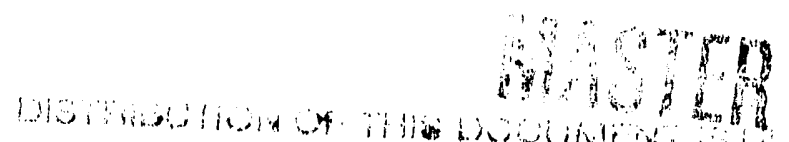




\subsection{OBJECTIVE}

The overall objective of this program is to integrate EER's expertise in boiler reburning performance evaluation into a package of analytical computer tools. Specific objectives of the program are to develop a computational capability with the following features:

(a) can be used to predict the impact of gas reburning application on thermal conditions in the boiler radiant furnace, and on overall boiler performance

(b) can estimate gas reburning $\mathrm{NO}_{\mathrm{x}}$ reduction effectiveness based on specific reburning configurations and furnace/boiler configurations.

(c) can be used as an analytical tool to evaluate the impact of boiler process parameters (e.g., fuel switching and changes in boiier operating conditions) on boiler thermal performance.

(d) is adaptable to most boiler designs (tangential and wall fire boilers) and a variety of fuels (solid, liquid, gaseous and slurried fuels).

(e) is sufficiently user friendly to be exercisable by engineers with a reasonable knowledge of boilers, and with reasonable computer skills. Here, "user friendly" means that the user will be guided by computer codes during the course of setting up individual input files for the boiler performance model.

\subsection{APPROACH}

The approach to the development of the reburning boiler process model is through the modification and integration of EER's current reburning system submodels. As with any comprehensive engineering computer models, the reburning submodels occupy a substantial amount of computer memory and usually require a list of inputs to describe the complex boiler environment. These submodels are considered to be too unwieldy to le directly incorporated into a single generalized design/evaluation procedure. As an alternative, the approach is to package these submodels into three main analytical tools, namely, a furnace heat transfer model, a boiler performance model, and a reburning $\mathrm{NO}_{\mathrm{x}}$ model. The coupling of process design information amongst the three submodels will be established through input/output interfaces, and through the use of boiler design data and any available field measurements.

\subsection{PROGRAM STRUCTURE}

In order to achieve the overall objectives, the execution of the program has been broken down into five tasks. These tasks and their individual objectives are briefly discussed in the following. 
Task 1. Development of a 2D Furnace Heat Transfer Model

Under this task, EER's 2D furnace heat transfer model (2DHT) will be modified for most boiler designs, firing configurations, as well as different fuels. Specifically, the 2D Model will be set up for treatment of tangential and wall fired boilers, and adapted to solid, liquid, gaseous and slurried fuels. The code will also incorporate the ability to describe gaseous reburning fuel injection, overfire air injection and flue gas recirculation.

In conjunction with the 2D Model modifications, Task 1 will also focus on modification and improvement of a guided input-code (2DINPT) so that the user will be guided stepwise through the necessary input routines, and will be provided with default values for certain key parameters. This input code will also be used by the user to update key model inputs for cases defined.

\section{Task 2. Developrent of a Boiler Performance Model}

The purpose of Task 2 is to develop a Boiler Performance Model which calculates steamand gas-side heat bala.ce for boiler sections that are not included in the domain of the 2D Model, such as the backpass convective section and air preheater. The approach taken to prepare the Boiler Performance Code will be in line with the preparation of the 2D Furnace Heat Transfer Model. EER's Boiler Performance Code will be modified and tested in responding to any changes made in the 2D Model to ensure mutual consistency. In addition, a separate input code for the operation of the Boiler Performance Model will be prepared in order to provide guidance to the user in input file preparations.

\section{Task 3. Development of a Reburning NO Model}

The purpose of this task is to develop a $\mathrm{NO}_{x}$ model which provides reasonable working estimates for the expected $\mathrm{NO}_{\mathrm{x}}$ reduction potential as a function of the major boiler process controlling parameters. The boiler process parameters include furnace gas temperature profiles and residence time distributions, local stoichiometries up- and down-stream of the reburning fuel injection zone, reburn fuel and overfire air local mixing rates, and injection locations.

To develop the Reburning $\mathrm{NO}_{x}$ Model, EER's chemical kinetics codes will firstly be modified to take account of a wide range of boiler operating conditions with the consideration of reburning zone injection temperature, stoichiometry, flue gas quench rates and residence times. The model will assume that mixing of both reburning tuel and overfire air is adequate so that bulk mixing rates of the injected jets can be represented by characteristic mixing times. The model will then be coupled with the outputs of the Furnace Heat Transfer Code which in turn incorporates the input of boiler-specific nformation such as temperature gradients and gas residence times. This model will predict $\mathrm{NO}_{\mathrm{x}}$ emissions for a specific set of boiler input and 
reburning conditions, so that the user will be able to evaluate $\mathrm{NO}_{\mathrm{x}}$ reduction potentials associated with the assumed operating conditions.

\section{Task 4. System Model Integration}

As discussed above, six computer codes (i.e., three input-codes, and three main-codes) will be developed upon completion of Tasks 1 to 3 . Task 4 will integrate these six computer codes into a complete boiler reburning model-package through input/output file connections. The operation of the boiler modeling package will be streamlined and kept as simple as possible to the user. This task will also carry out testing and performance evaluation of the integrated computer package. Example cases will be selected to demonstrate the use of different model options and capabilities.

\section{Task 5. Document Preparation and Model Delivery}

This task consists of two major reporting items: Preparation of a User's Manual, and provision of consulting and short courses. The purpose of this task is to assist the user in applying the boiler model-package, and to provide necessary support until he become familiar with the operation of the computer codes.

The manual will be constructed to include: (a) a brief description of the physical and chemical basis of the models, (b) a complete description of the model applicability, options and input/output, (c) a description of the default inputs, (d) a detailed description of worked examples. The Reburning Boiler Performance codes will be structured in PC formats. Executable versions of the codes will be prepared in the form of floppy disk sets and delivered with the User's Manual.

This task will also provide telephone consultation service for a limited time period following delivery of the Reburning Boiler Performance Model. A three-day short course instruction will be provided on the basis of necessity.

\subsection{TECHNICAL PROGRESS}

During this reporting period, the model developmental effort has focused on modification of the 2D heat transfer code, in order to accommodate the various options as stated in the work scope of Task. 1. Specific progress and accomplishments are summarized in the following.

\section{(a). Completion of the Furnace Input Code (2DINPT)}

Extensive code modifications and testing have been carried out on the furnace input-code. 
Completed items which are of significance to the users are:

- Modifications for gas and oil firing

- Modifications for reburn/co-firing options

- Addition of default values for oil and gas firing

- Improvement on the ease of use in flow field descriptions

- Improvement on the quality of user/computer interactive communications

The completed 2DINPT Code has been tested for several assumed boiler cases which fired different fuels such as coal, oil, and gas. The results indicate that the code is fully functional and performs as designed. A sample output for a gas-fired furnace is shown in Appendix A. Additional refinement of the 2DINPT code is expected as the development of other computer codes continues. However, the extent of future modifications would be relatively narrow compared to those already have been accomplished.

\section{(b). Modification and Testing of the Furnace Code (2DHT)}

In conjunction with the work accomplished in item (a), the Furnace Code has been modified to include additional capabilities. These modifications include abilities to handle oil and gas fired furnaces, and fuel co-firing/reburning applications. For oil firing, the code can include the use of steam for fuel atomization. Codings for reburning applications, including the use of FGR for reburn gas injection, have also been placed. In addition, a large portion of the code have been re-structured to improve computational efficiency and output flexibility.

The revised 2DHT Code has been tested for coal, gas, and oil firing. Satisfactory results have been obtained for the oil and coal cases. However, difficulties of numerical instability had occurred for the oil firing cases. The cause of this instability has been identified, and work is continued to improve the ability of the code to handle oil-fired furnaces. Appendix B shows the format of the model outputs for a preliminary test case with oil firing.

\subsection{PLANS}

The next reporting period will focus on the remaining of the tasks, especially, on the execution of the following items which are listed in order of priorities:

- Completion of the Furnace Code modifications and testing

- Development of the $\mathrm{NO}_{\mathrm{x}}$ Model and an input-code for the $\mathrm{NO}_{\mathrm{x}}$ Model.

- Preparation of the Boiler Performance Model

- Model integration 
Presei C key to change the valuea

Return to continue

specify a two-diglt varalon number (NRVs) for

current run (0.0., 01, 02, or 03): 01

- Verion number can be uned to further document caseo run under the same cave number as opecified above

Prese: C key to change the values

Retura to continue

spocley boller load (CLOAD) for curreat run: 100.

- Boller lond my be dever1bed a $60.5,90.0$, or 100.0 ,

to bow the of current load relutive to the bollar MCR

Proser C kay to chango the valuea

Return to continue

Name of 1Dput dara \$1lo (PINPT):

- Default E110 nam 10 2DINPT. DAT

2alnpt.dat

Prosis: D key for default values

C key to change the values

Return to continue

Name of 1pput array f110 (RINPTAR): IARR0201

- The dofault name has format as IARRCEVS.LLL

- IARR denotes "Input array"

- CSVS repreant the case number and the version numbers

- . LLL shows the bollar load percentage.

Prosa: D key for dofault values

C key to change the values

Return to continue

Name of output array 1110 (FINPTAR): OARR0201

- The default name bas format as OARRCSVS.LLL

- OARR denoten "output array"

Preas: D key for default values

C koy to change the values

Return to continue

Name of output graph1c P110 (FGRFOPT): GRFO

- The default name bas format a GRFOCSVS.LLL

- GRPO denotes "graph1c array"

Prass: D kay for default values

C key to change the values

Return to continue

Name of olxtput printer 112e (FHDOPT): haot 0201

- The default name has format as HDOTCSVS.LLL

- HDOT denotes "printer file"

Presa: D key for the default file name

C key to change the flie name

B key to direct the file to your monitor

Return to continue

Speciflcation of output level (LOUTPUT) :

Current output level 18 DEFAULT

- DEFAULT aetting is most useful and recommended

-. In adaltion to the default oetting, you can choose from four other output levels: 1, 2, 3, and 4

- Higher output levelo glve more comprehehgive information

Pregs: D key for defau't values

C key to change the values 


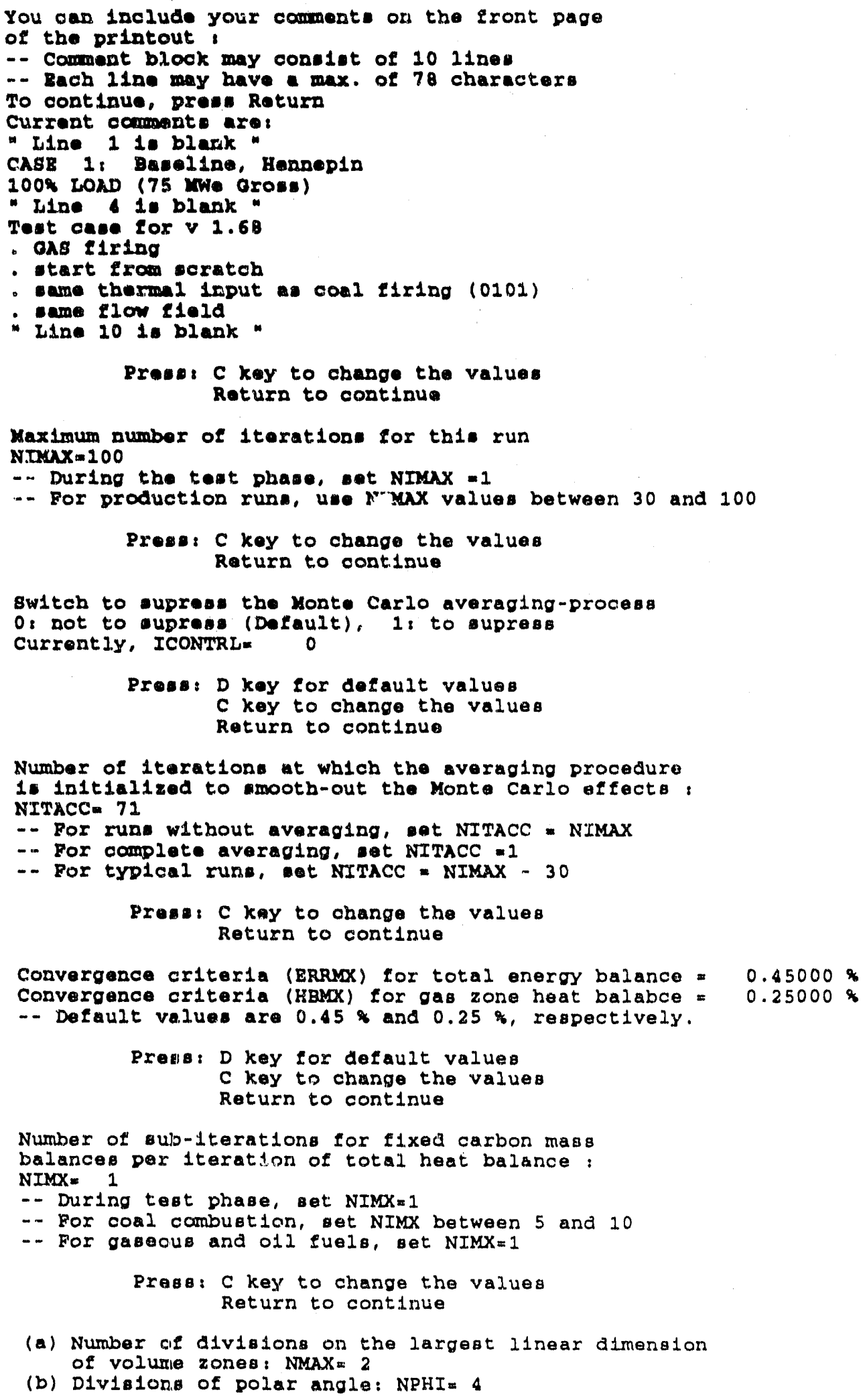

Number of 1tarations at which the averaging procedure 1. In1t18l1zed to mootb-out the Monte carlo effects NIMACC. 71

- For run w1tbout averaging, eet NITACC = NIMAX

-- For complete averaging, at NITACC =1

-- Por typlcal rune, ot NITACC = NIMAX - 30

Preas: C kay to change the values Return to continue

Convergence criter1a (ERRXX) for total energy balance = $0.45000 \%$ Convergance crlterla (HBMX) for gas zone heat balabce $=0.25000 \%$ - Default values are $0.45 \%$ and $0.25 \%$, respectively.

Number of aub-1terations for f1xed carbon mass balances per 1teration of total heat balance: $N I M X=1$

-- During test phase, set NIMX=1

- For coal combuetion, set NIMX between 5 and 10

- For gaseous and o1l fuels, set NIMX=1

Prese: C key to change the values Return to continue

(a) Number cif diviolons on the largent innear dimension of volume zone日: NMAX= 2

(b) Diviolone of polar angle: NPHI=4 
(c) Cut-off value for baam tracking: ExACT:0.000100

Default values are: $\max =2$

NPHI $=4$

EXACT $=0.0001$

Nwax and NPHI muet be oven number

Prese; D key for default values

C key to change the values

Return to cont1nue

Number of 1teration after whioh fleld variables

of total heat balances are printed:

NPRIN- 100

-- Dafault value 1. NPRIN=NDUXX (recommended)

Proser D key for dofault valuea

C key to change the value

katura to cont1nue

8witob for printing mena andouvitias along furnace:

0 : to turn-oef. 1: to tura-on this option

Currently, IPATBA.

Prase: C key to change the values

Retura to cont1nue

Switchs to print detalied output of:

- total energy balance for volume and ourface zones

-- mass balance for volume zones

Enter: $Y$ kay to print

N key to upreas

Return to continue

Switches to write or read elles to/from hard diak:

NWRTE: Sw1tch to ave data l1le at the end sit the 2 DHT run Currently, NWRTE = 1

NREAD, Switch to read vartable values from a restarting

11. at the beglaning of the 2 DHT run

Current $2 Y$, NREAD $=0$

-- For trial run , cet NWRTEm 1 and NREAD=0

... For cont1nued runs, ot NWRTE=1 and NREAD $=1$

Presu: C koy to change the values

Return to continue

NWRTE = 1, NREAD. 0, Are these values $0 . K$. ?

Proas: C kay to change the values Return to continue

Chapter 2 :

GOILER FURNACE OPERATING DATA

Preas: p key to by-pasa th1s chapter

$R$ key to bave file and exit 2 DINPT

Return to proceed through this chapter

FUEL TYPE

For gaseous tuels, eet NGAS $=1, N L I Q=0, N S L L=0$

For 11quid fuels, set NGAS $=0, N L I Q=1, N S L L=0$

For olla fuela, set NGAS $=0$, NLIQ: $0, N S L L=1$

Current IY, NGAS 1 NLIQ $=0$ NSLI $=0$

Press: C key to change the values

Return to continue

You chose gas as fuel 


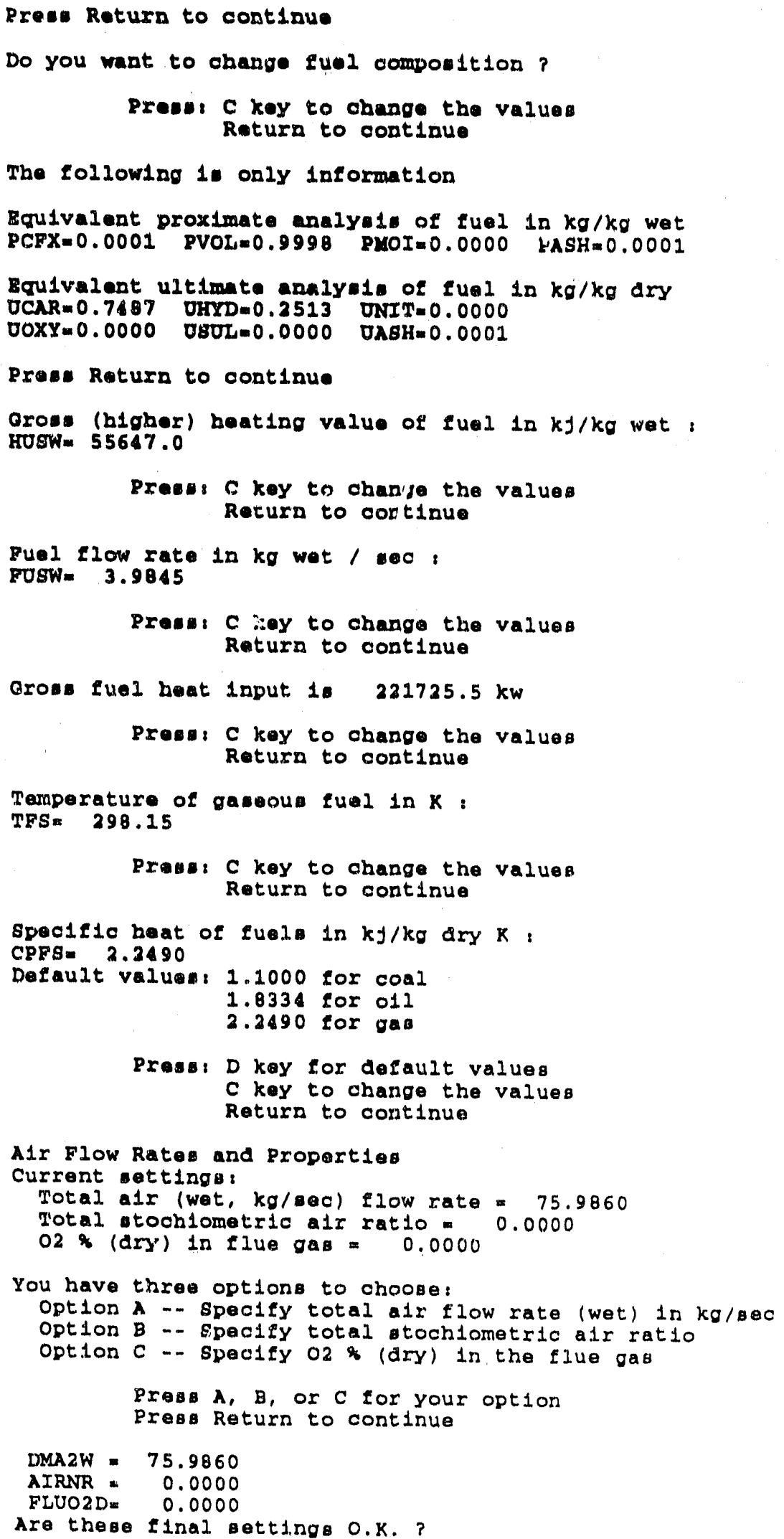


Prenei C key to change the values Return to continua

Watar vapor nontant in a1x

(a) Relative bumla1ty in RELHA. 50.0000

(b) Saturation preature in bar, PgH2A2=0.0317

Default value axo 50 and 0.0317 bar at $298.15 \mathrm{~K}$

Preasi D kay for degault valuas

C key to change the values

Return to continuo

Temperature of secondary a $1 x$ in $K$;

$T A 2=545.47$

Preae: C key to change the values

Return to continue

Amount of primary air in * of otolohicmatric atr :

PASTCH $=20.0$

Default value $1.20 \%$

Preas: D key for default values

C key to chango tho values

Return to continue

Convective heat tranefer coefflolent at furnace wallo

in $\mathrm{kw} / \mathrm{m} * 2 \mathrm{~K}: \mathrm{NLPHA}=0.0116$

Default value $100.0116 \mathrm{kw} / \mathrm{m} * 2 \mathrm{~K}$

Press: D key for default values

C key to change the values

Return to continue

Cool 1de temperature of furnace walls in K: TOUTm634.00

Default valuo $1.750 .0 \mathrm{~K}$

Prees: D key for default values

C key to change the values

Return to continue

Chapter 3 :

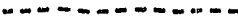

INIPIAL COAL PARTICLE SIZE DISTRIBUTION

Prose: p kay to by-pase this chapter

$R$ key to ave elle and exit 2 DINPT

Return to proceed through this chapter

Cas Firlno:

Default values havr, been automaticaliy set

Presa Retuxn to continue

Chapter 4 :

- - - - - - - - - - -

PARAMETERS FOR CHAR AND VOLATILE BURN-OUT

Preas: P key to by-pags this chapter

$R$ key to bave flld and exit 2 DINPT

Return to proceed through this chapter

Fuel "Volat1le" Burnout Character2st1cs

"Volat1le" burnout time in oec: TLFMAX = 0.78

- Default values are $0.7 \mathrm{gec}$

- For highly owlrling flow set TIFMAX $=0.4$

- For delayed mixing Ilame Buch for T-Eired

bollex, aet TLFMAX=1.4

Press: D key for default values 
C key to obange the values

Retura to continue

Number of lump uned to represent fuel "volatile"

combustion i NVLTOT. 10000.

- Derault value 1. 10000 .

Prese: D key for default valuas

C key to change the values

Roturn to cont1nue

Fractlonal converolon of "volat1le" carbon to soot:

CXCVL8: 0.00

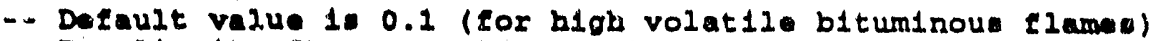

- Por I1onite elames, set to 0.05

- For heavy oll elamen, wat to 0.2

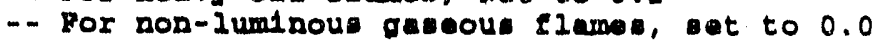

Prean: D key for dofault valuea

C koy to change the values

Retura to continue

Chapter 5 :

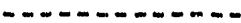

PARAMETERS FOR SORBENT REACTIVITIES

Prones P key to by-pass th1 chapter

$R$ key to cave flie and exit 2 DINPT

Return to proceed through this chapter

switob to exercise corbent lujection option:

NSORB 0

- To axercise sorbent Infection option, set NSORB: 1

Otherw1se, oet NSORB=0

-- Default value 1s NSORB= 0

Prese $D$ key tor desault values

C key to change the values

Roturn to continue

Th1. 1. only 1nformation

Flag NELOLD for flow lleld tatus:

NFLOLD 1

Fraction of total bulfur as pyritic sulfur:

PRSULP= 0.3665

-- Defalit value 1 . 0.0

- For gas and 011 flring, may set to 0.0

Prese: D key for default values

C key to change the values

Return to continue

Chapter 6 :

PARAMETERS FOR PARTICLE SCATTERING

Press: P key to by-pass this chapter.

$R$ key to gave flle and exit 2 DINPT

Return to proceed through this chapter

Switch for ash particle scattering

0 : to turn-off, is to turn-on this option

Currently, NNSCT: 0

Pres8: C key to change the values

Return to continue

Chapter 7 : 
SPECIPICATION OF FORNACE MODEL GBOKETRY

Preoe: 2 key to by-pase thla chapter

$\mathrm{R}$ koy to save 120 and exit 2 DINFm

Retura to proceed through this chapter

Number of volume zones in X-alrection, NXu22

Prese: C key to change the values

Return to continue

Number of volume zones in $Y \cdot d 1$ rection, NY: 4

Prans: C key to change the values Return to cout1nue

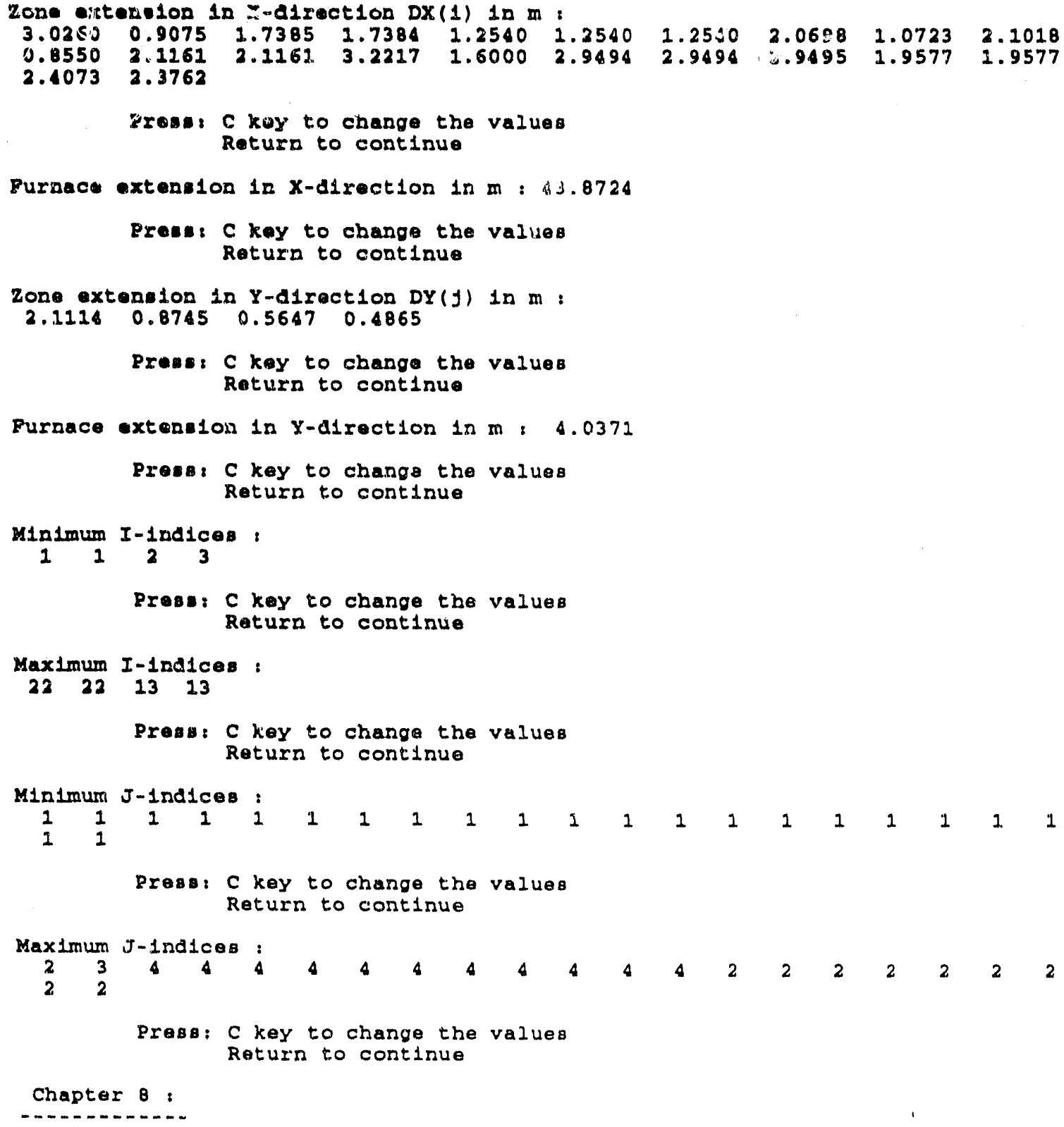


PARAMETERS FOR REBURNINO OR CO-FIRING

Press: $p$ key to by-pasa thia chapter

$R$ key to ave I1le and exit 2 DINPT

Return to proceed through thia chapter

Switch for roburaing or co-Elring

o: to turn-ofe. 1: to turn-on this option

Current ly, NREB = 0

Press: C key to change the ralues

Raturn to continua

Chapter 9 :

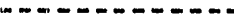

SPECIFICATION OF HEAT EXTRACTIONS

Prose: P key to by-pass th1s chapter

$R$ key to save flle and exit 2 DINPT

Return to proceed through this chaptex

Heat Extraction by Heat sinks

Option $A$ : No additional surface area

Option B: Cooled surface area located at olrcumferent1al walle $(M=4)$ of a refractory coverud furnace

Option C: simulation of radiant heat exchangers in upper furnace

Currently option $C 1$ exercised

Press: C key to change Return to continue

-.- Simulation of Radiant Heat Exchangers -.-

Press: p key to by-pass this aection

$R$ key to save 11 e and exit 2 DINPT

Return to proceed through this section

(a) Lower Index of I zone layerg occupled by the - Imulated heat exchangers: ISHL=19

(b) Opper Index of I zone layere vccupled by the - Imulated heat exchangere: ISHU $=22$

Preso: C key to change the values Return to continue

Heat exchanger geametric configurations

Press: P key to by-pase this aubsection Return to proceed through

ZONE LAYER I $I 9$

Total heat oink surface area $(m * * 2)$

at $I=19 \quad 1$ B 282.7989

-. Set co 0.0 if 1t is a cavity.

Preas: C key to change the values

Return to continue

Outer diameter of exchanger tubes (m)

at $I=191 \mathrm{~s} 0.054000$

Press: C key to change the values

Return to continue

Simulation of heat exchanger arrangement at $I=19$ 


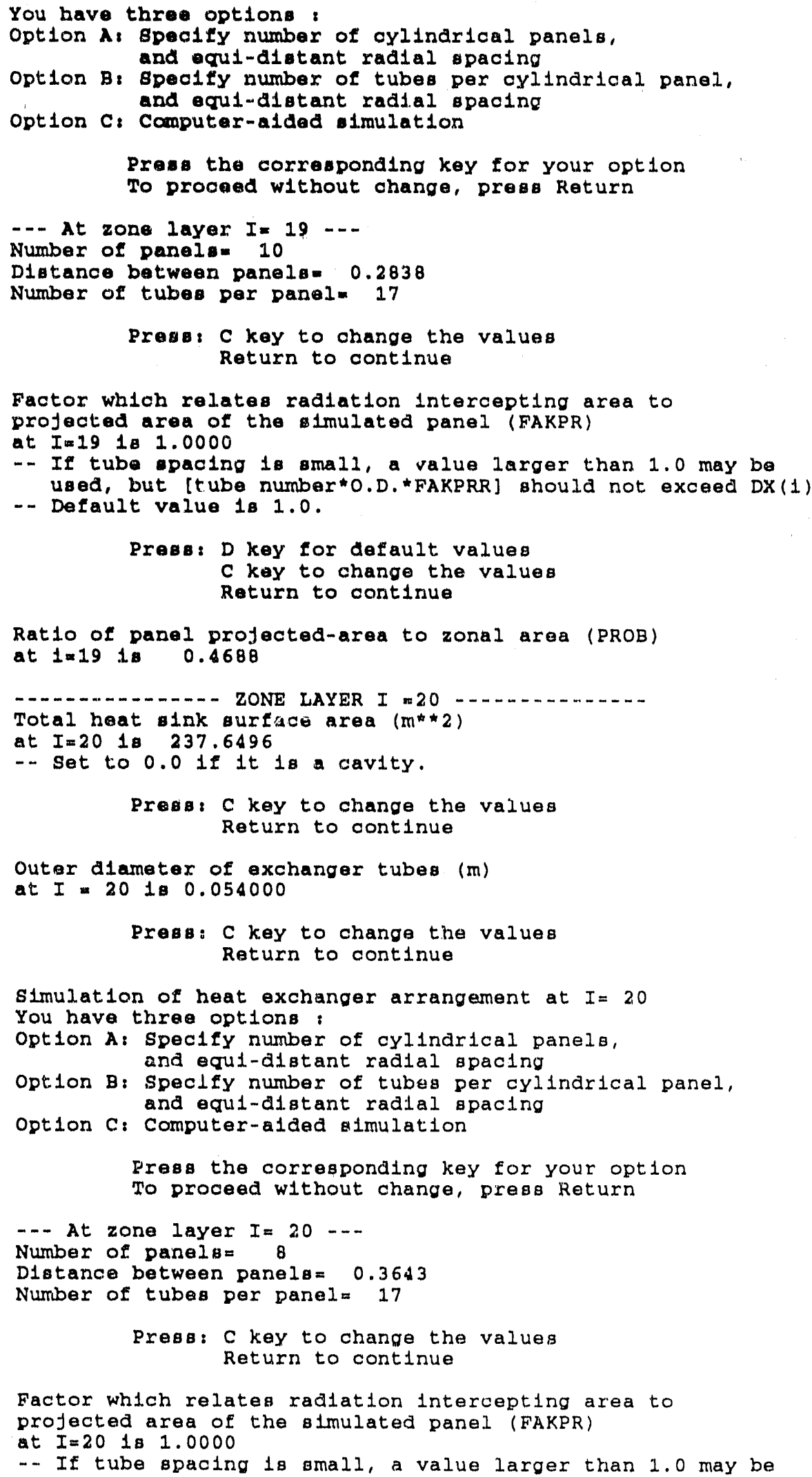

Factor whlch relates radiation 1ntercept1ng area to profected area of the simulated panel (FAKPR)

at $I=20$ 1. 1.0000

- If tube spacing 18 gmall, a value larger than 1.0 may be 
used, but [tube number*O.D. FAKRRR] should not exceed DX (1) - Default value i. 1.0 .

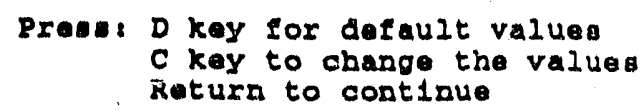




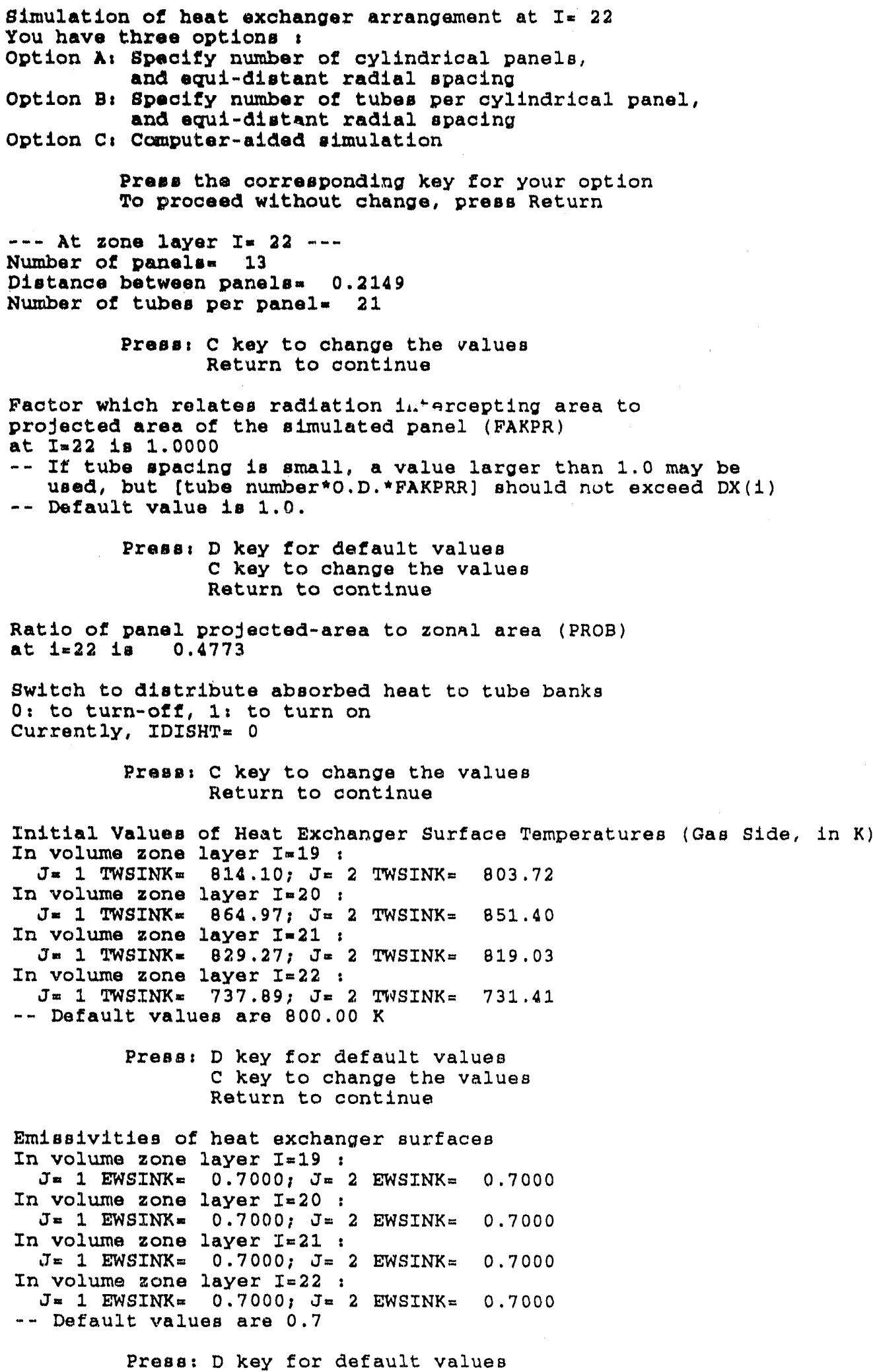

Emlosivities of heat exchanger surfaces In volume zone layex $I=19$ :

$J=1$ EWSINK $=0.7000, J n 2$ EWSINK $=0.7000$

In volume zone layer $I=20$ :

$J=1$ EWSINK $=0.7000 ; J=2$ EWSINK $=0.7000$

In volume zone layer $I=21$ :

$J=1$ EWSINK $=0.7000 ; \quad J=2$ EWSINK $=0.7000$

In volume zone layer $I=22$ :

$\mathrm{J}=1$ EWSINK $=0.7000 ; \mathrm{J}=2$ EWSINK $=0.7000$

- Default valuea are 0.7

Presa: D key for default values 


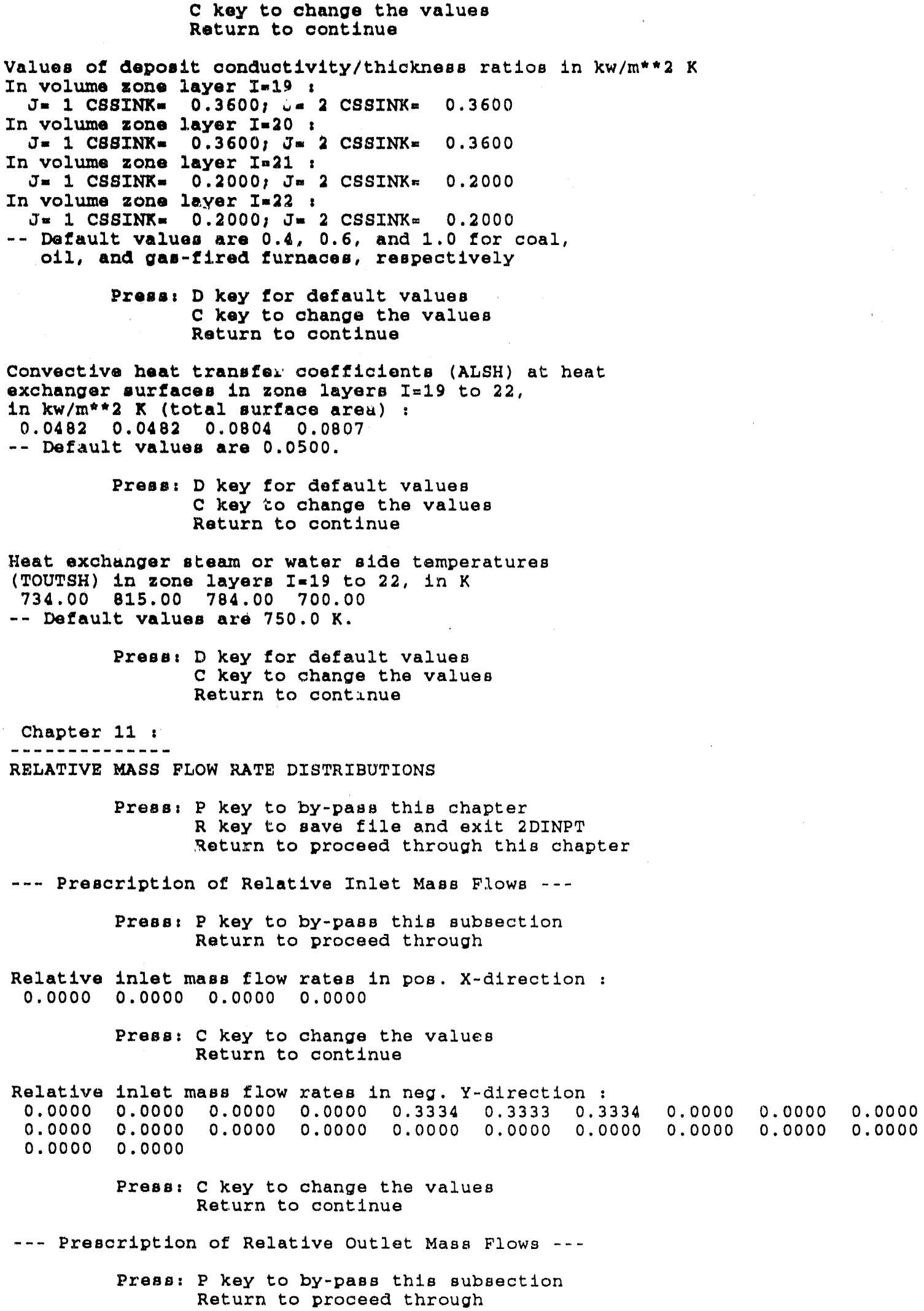




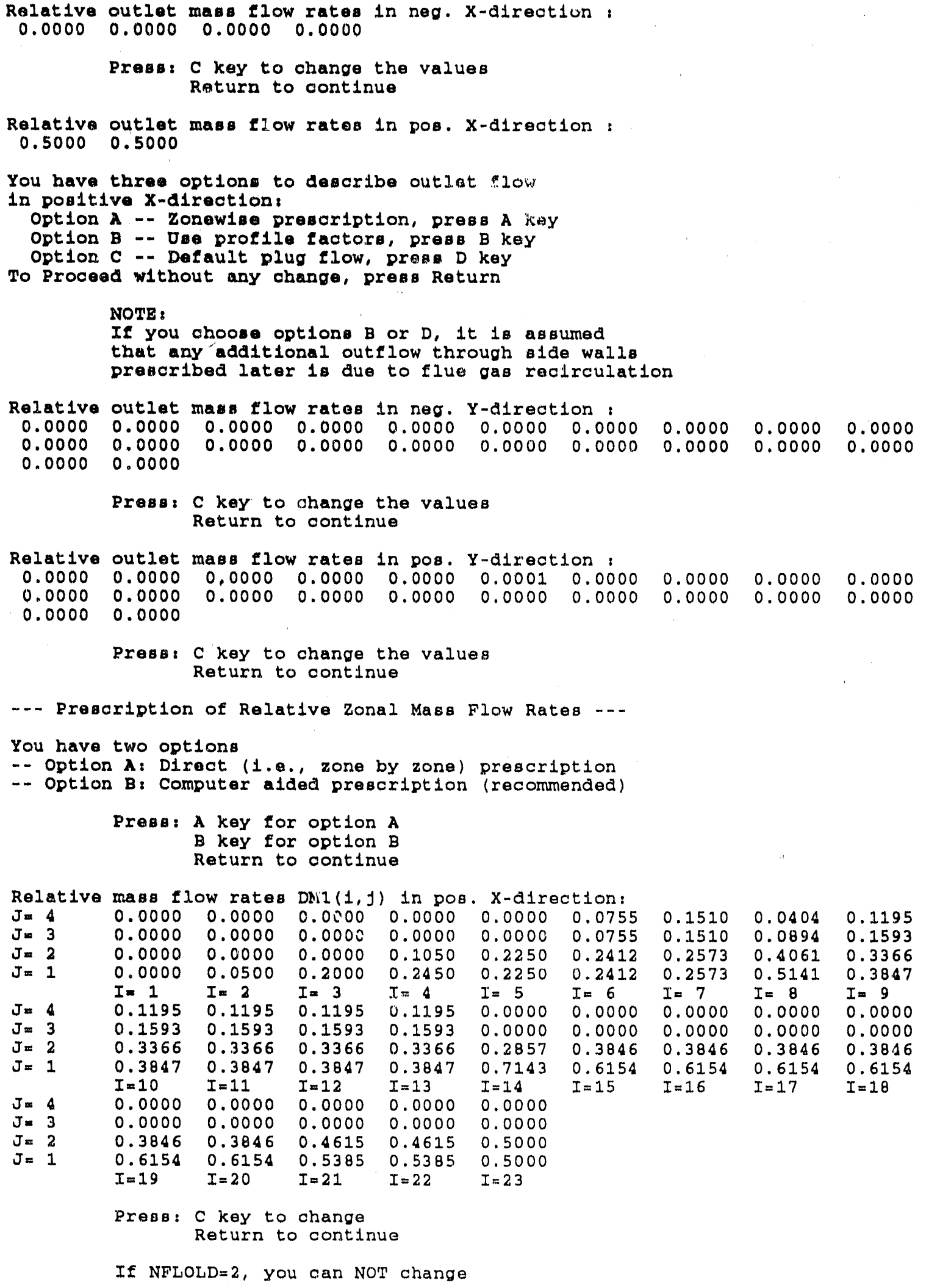

Relative mass $f$ low rates DNi $(1, f)$ in pos. $x$-alrection:

$\begin{array}{llllllllll}J=4 & 0.0000 & 0.0000 & 0.0000 & 0.0000 & 0.0000 & 0.0755 & 0.1510 & 0.0404 & 0.1195 \\ J=3 & 0.0000 & 0.0000 & 0.0000 & 0.0000 & 0.0000 & 0.0755 & 0.1510 & 0.0894 & 0.1593 \\ J=2 & 0.0000 & 0.0000 & 0.0000 & 0.1050 & 0.2250 & 0.2412 & 0.2573 & 0.4061 & 0.3366 \\ J=1 & 0.0000 & 0.0500 & 0.2000 & 0.2450 & 0.2250 & 0.2412 & 0.2573 & 0.5141 & 0.3847 \\ J=4 & I=1 & I=2 & I=3 & I=4 & I=5 & I=6 & I=7 & I=8 & I=9 \\ J=4 & 0.1195 & 0.1195 & 0.1195 & 0.1195 & 0.0000 & 0.0000 & 0.0000 & 0.0000 & 0.0000 \\ J=3 & 0.1593 & 0.1593 & 0.1593 & 0.1593 & 0.0000 & 0.0000 & 0.0000 & 0.0000 & 0.0000 \\ J=2 & 0.3366 & 0.3366 & 0.3366 & 0.3366 & 0.2857 & 0.3846 & 0.3846 & 0.3846 & 0.3816 \\ J=1 & 0.3847 & 0.3847 & 0.3847 & 0.3847 & 0.7143 & 0.6154 & 0.6154 & 0.6154 & 0.6154 \\ J=1 & I=10 & I=11 & I=12 & I=13 & I=14 & I=15 & I=16 & I=17 \\ J=4 & 0.0000 & 0.0000 & 0.0000 & 0.0000 & 0.0000 & & I=18 & & \\ J=3 & 0.0000 & 0.0000 & 0.0000 & 0.0000 & 0.0000 & & & \\ J=2 & 0.3846 & 0.3846 & 0.4615 & 0.4615 & 0.5000 & & & & \\ J=1 & 0.6154 & 0.6154 & 0.5385 & 0.5385 & 0.5000 & & & & \end{array}$

Prese: C key to change Return to continue

If NFLOLD $=2$, you can NOT change 
Relative mass clow rate $\operatorname{DM} 3(1, j)$ in neg. $\mathrm{X}$-direction

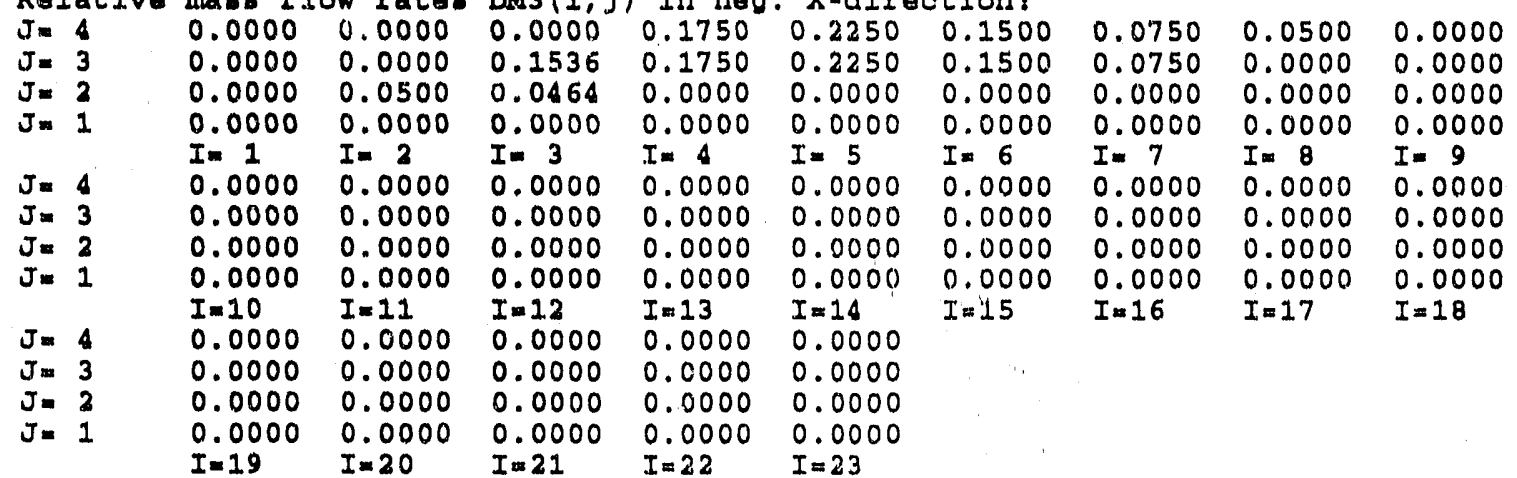

Prese: C key to change

Return to continue

If NFLOLD=2, you can NOT change

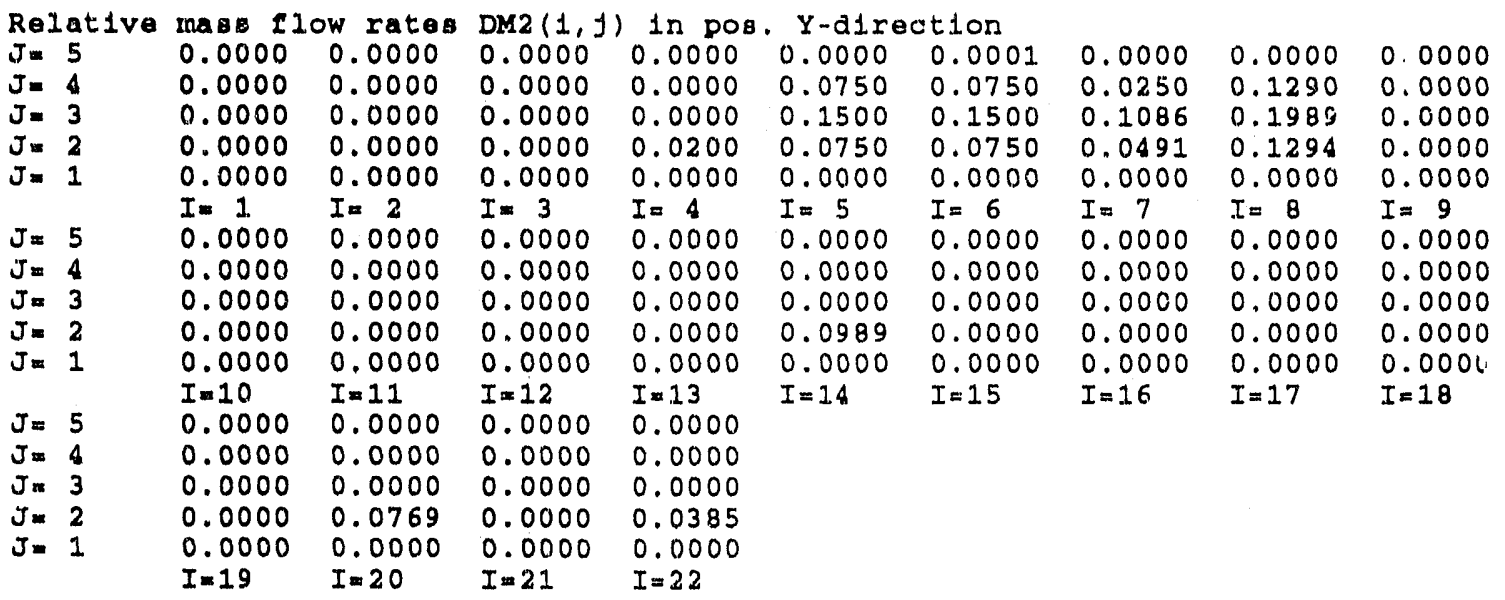

Press: C key to change

Return to continue

IE NELOLD=2, yOu can NOT change

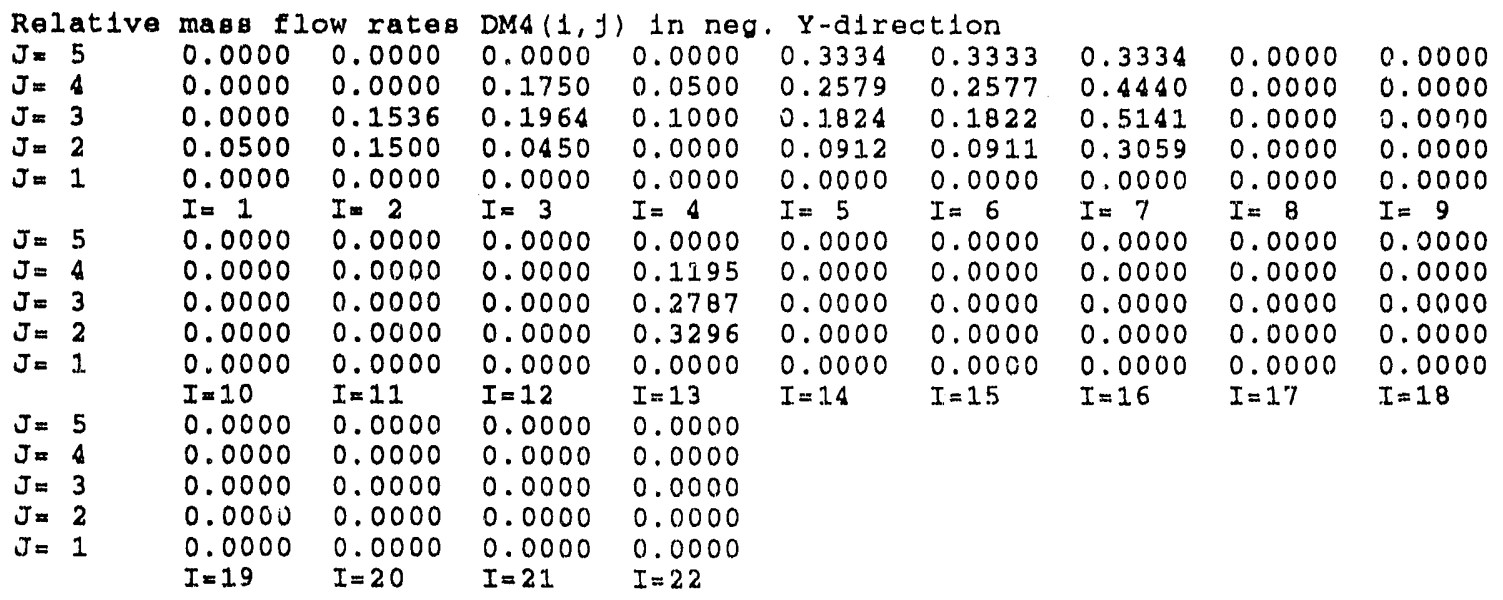

Presa: C key to change

Return to continue 
If NFLOLD=2, you can NOT change

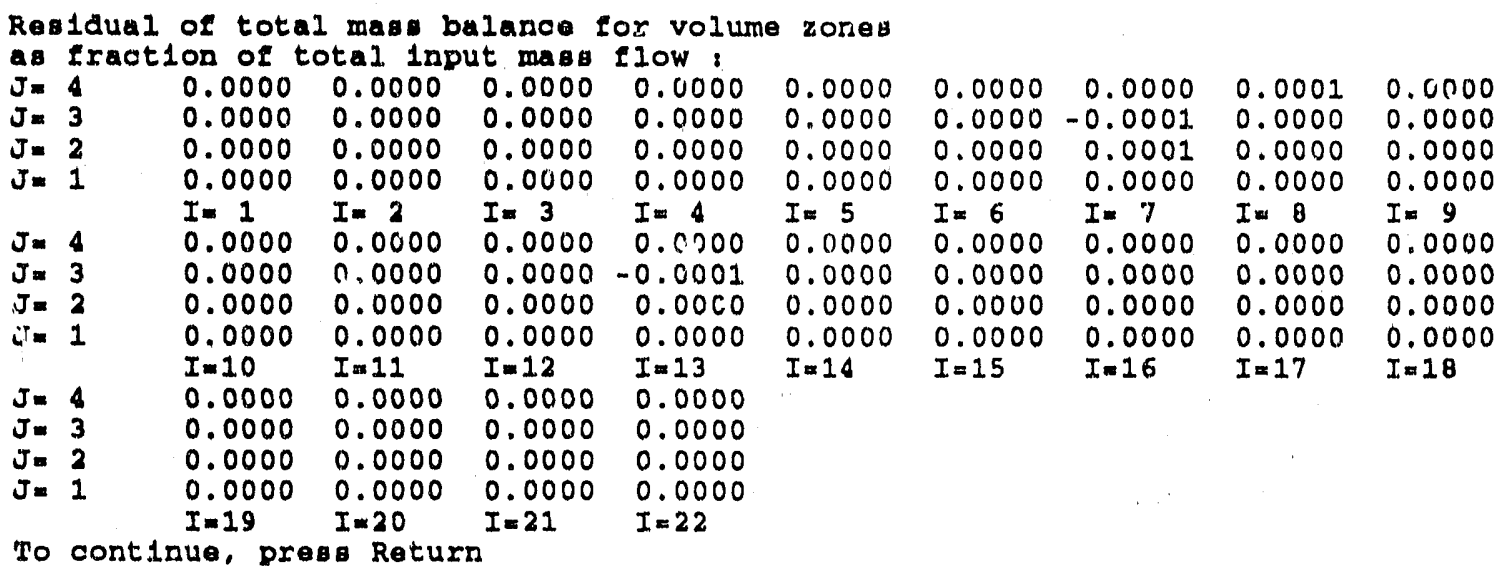

Chapter 12 :

PRESCRIPTION OF RECIRCULATING FLOW FIELD

Prese: P key to by-pasa this chapter

$R$ key to arve file and exit 2 DINPT

Return to proceed through this lhapter

Reciroulating flow over crose-section $I=2$

1s $5.00 \%$ of total inlet mass flow.

Prese: C key to change the values Return to continue

Reciroulating flow over cross-section $I=3$

1. 20.00 \% of total inlet masa flow.

Presa: C key to change the values Return to continue

Reclrculating flow over crose-section $I=4$ 18 $35.00 \%$ of total inlet masa flow.

Preas: C key to change the values Return to continue

Recirculating flow over cross-section $I=5$

$1 \mathrm{~s} 45.00$ \% of total inlet mass flow.

Press: C key to change the valueg Return to cont1nue

Recirculating flow over crosg-section $I=6$ 18 30.00 \% of total inlet masa flow.

Preas: C key to change the values Return to continue

Recirculating flow over crose-section $I=7$

1B 14.99 \% of total inlet mass flow.

Press: C key to change the values Return to continue

Recirculating flow over cross-sectlon $I=8$

1s 4.99 \% of total inlet mass flow. 


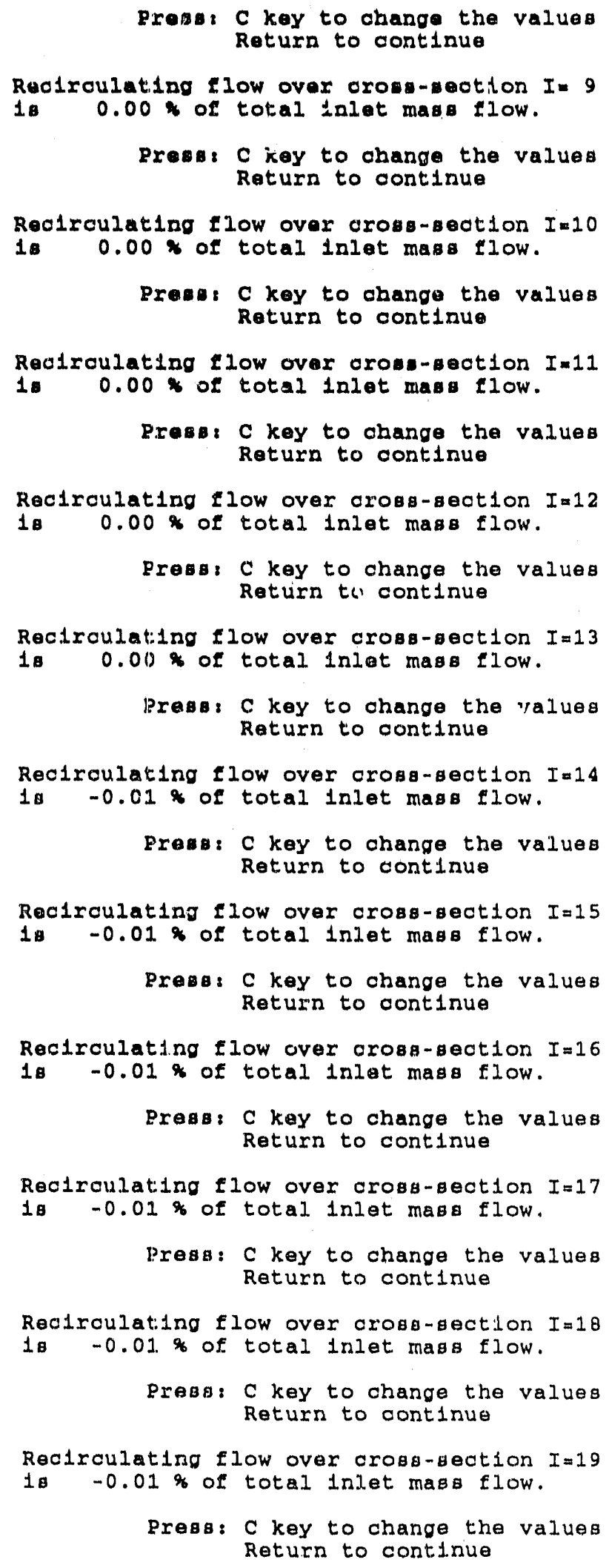

Press: C key to change the values Return to continue 
Rec1roulating tlow over crom-neot 1 on $I=20$

$18-0.01$ of total lalet mass flow.

Prese: C key to ohange the values Return to continue

Reciroulating tlow over orosa-geation $I=21$

1. -0.01 of total 1nlet mass low.

Preas: C key to change the values Return to continue

Rec1rculating flow over cross-section $I=22$ 18 -0.01 of total inlet mass low.

prese: C key to ohange the values Return to ooritinue

Normalized velooltion in Y-alreation

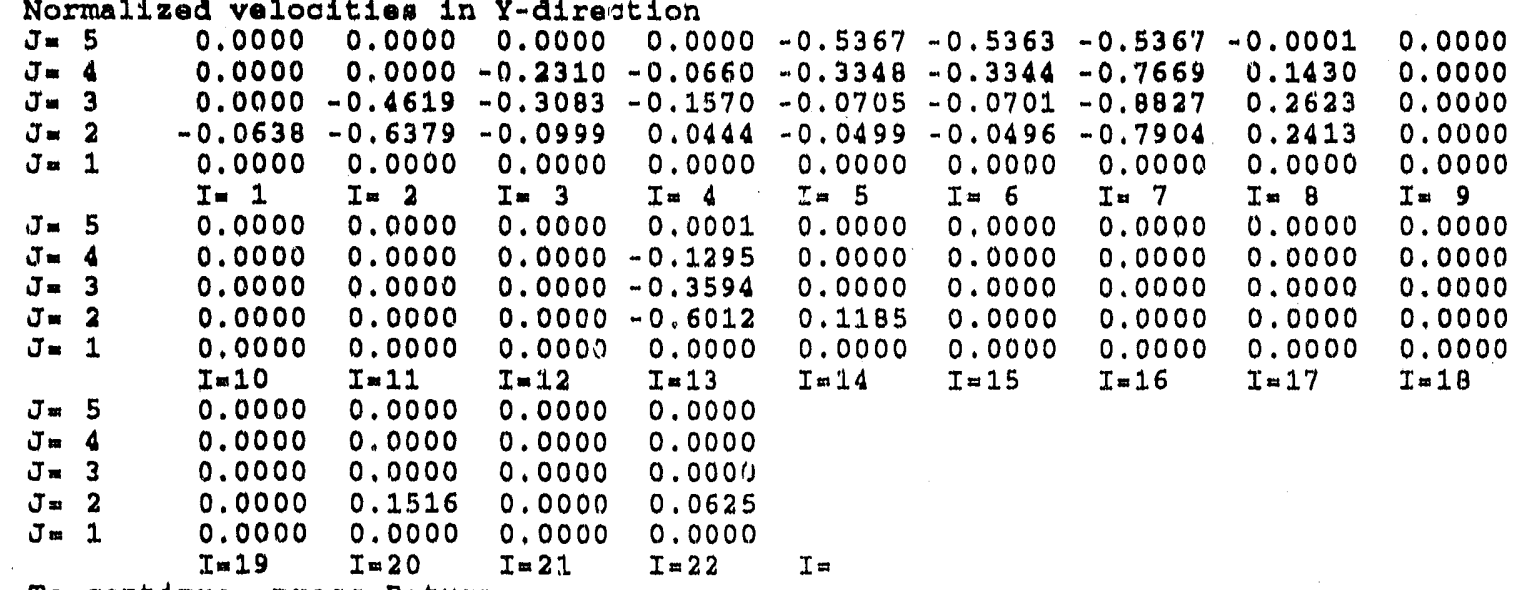

To continue, preas Return

Chaptar 13 :

PRESCRIPTION OF TURBULENT MASS FLUX VECTORS

proos: P key to by-pase this ohapter

R key to mave elle and exit 2DINPT

Return to proceed through this ohapter

Th1 18 the current relative turbulent mass flux

I 101d with respect to the $x$-direct 100

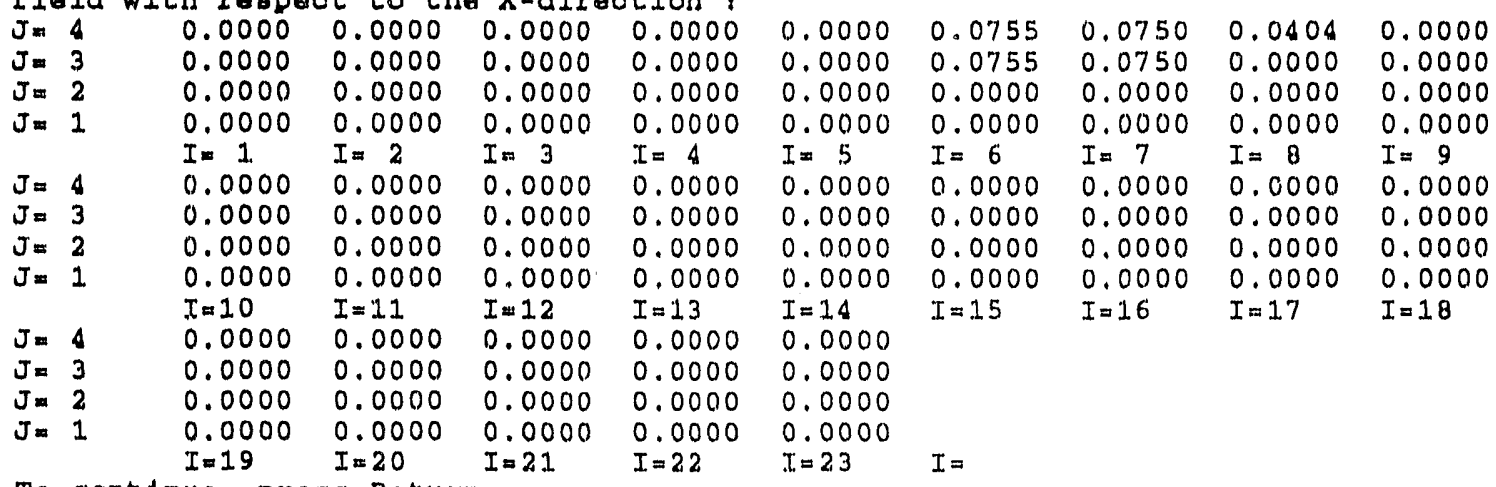

To continue, presa Return

This is tho ourrent turbulent masg flux flela

with respect to the $\mathrm{y}$-direction:

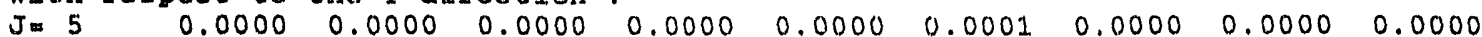




\begin{tabular}{|c|c|c|c|c|c|c|}
\hline $\begin{array}{l}J=4 \\
J=3 \\
J=2 \\
J=1 \\
J=5 \\
J=4 \\
J=3 \\
J=2 \\
J=1 \\
J=5 \\
J=4 \\
J=3 \\
J=2 \\
J=1\end{array}$ & $\begin{array}{l}0.0000 \\
0.0000 \\
0.0000 \\
0.0000 \\
I=1 \\
0.0000 \\
0.0000 \\
0.0000 \\
0.0000 \\
0.0000 \\
I=10 \\
0.0000 \\
0.0000 \\
0.0000 \\
0.0000 \\
0.0000 \\
I=1.9\end{array}$ & $\begin{array}{l}0.0000 \\
0.0000 \\
0.0000 \\
0.0000 \\
I=2 \\
0.0000 \\
0.0000 \\
0.0000 \\
0.0000 \\
0.0000 \\
I=11 \\
0.0000 \\
0.0000 \\
0.0000 \\
0.0000 \\
0.0000 \\
I=20\end{array}$ & $\begin{array}{l}0.0000 \\
0.0000 \\
0.0000 \\
0.0000 \\
I=3 \\
0.0000 \\
0.0000 \\
0.0000 \\
0.0000 \\
0.0000 \\
I=12 \\
0.0000 \\
0.0000 \\
0.0000 \\
0.0000 \\
0.0000 \\
I=21\end{array}$ & $\begin{array}{l}0.0000 \\
0.0000 \\
0.0000 \\
0.0000 \\
I .2 \\
0.0000 \\
0.0001 \\
0.0000 \\
0.0000 \\
0.0000 \\
I=13 \\
0.0000 \\
0.0000 \\
0.0000 \\
0.0000 \\
0.0000 \\
I .22\end{array}$ & $\begin{array}{l}0.0750 \\
0.1500 \\
0.0750 \\
0.0060 \\
I=5 \\
0.0000 \\
0.0000 \\
0.0000 \\
0.0000 \\
0.0000 \\
I=14\end{array}$ & $\begin{array}{l}0.0750 \\
0.1500 \\
0.0750 \\
0.0000 \\
I .6 \\
0.0000 \\
0.0000 \\
0.0000 \\
0.0000 \\
0.0000 \\
I=15\end{array}$ \\
\hline
\end{tabular}

0.0250

0.1086

0.0491

0.0000

I. $=7$

0.0000

0.0000

0.0000

0.0000

$I=16$
0.0050

0.0000

0.0000

0.0000

$I=8$

0.0000

0.0000

0.0000

0.0000

0.0000

$I=17$
0.0000

0.0000

0.0000

0.0000

$I=9$

0.0000

0.0000

0.0000

0.0000

0.0000

$I=18$

You have three options to modicy the turbulent fleld

option A Defauit distribution oaloulated by the 2DHY program (recomanded)

Option B No turbulenoe at all

option C : Column- and row-wiee presariptions

Pran: correaponding key for your opilon Return to continue

Reslaual of total mas balance for volume zones

a eraction of total input masa tow:

I. $\quad 0.0000 \quad 0.00000 .00000 .0000$

$J=2 \quad 0.0000 \quad 0.0000 \quad 0.0000 \quad 0.0000$

$T=1$

0.0000

0.0000

0.0000

0.0000

0.0000

I. 1

$I=2$

$I=3$

$I=4$

$I=5$

0.0000

0.0000

0.0000

0.0000

0.0000

0.0000

Jn 4

$\begin{array}{lllll}0.0000 & 0.0000 & 0.0000 & 0.0000\end{array}$

0.0000

$I=6$

0.0000

0.0000

0.0000

$I=8$

0.0000

0000

0.0000

$I=7$

$J=3$

$0.0000 \quad 0.0000 \quad 0.0000 \quad 0.0000$

0.0000

0.0000

0.0000

0.0000

$I=9$

J. 1

$0.0000 \quad 0.0000$

$0.0000 \quad 0.0000$

0.0000

$0.0000 \quad 0.0000$

0.0000

$1=0.000$

0.0000

0.0000

0.0000

0.0000

0.0000

0.0000

0.0000

0.0000

0.0000

$I=10$

$I=11$

$I=12$

$I=13$

$I=14$

$I=15$

$I=16$

0.0000

0.0000

$J=3$

$\begin{array}{lllll}0.0000 & 0.0000 & 0.0000 & 0.0000\end{array}$

$J=a$

0.0000

0.0000

$0.0000 \quad 0.0000 \quad 0.0000 \quad 0.0000$

Im 10

$I=20$

$I=21$

$I=22$

To continua, press Return

Chaptex 14 ,

FUEL INLET FLOWS

Preas: R kay to by-pasa this ohapter

IN key to save file and exit 2DINPT

Return to prooeed through this chapter

Rolativo Fuel Inlat Flow Ratos:

Default diatribution asumes fuel talot flowg are

proportional to total masa flow rates, 1.e., burrers

are 1red at ame otolohlometry

Preas: D key for default distribution Return to continue

Preaciption of Relative Fuel Inlet Flow Rateo

Relative flul inlet thow rateg in pos. X-clrection,

$0.0000 \quad 0.0000 \quad 0.0000 \quad 0.0000$

Press, C key to ahange the values 
Retura to continue

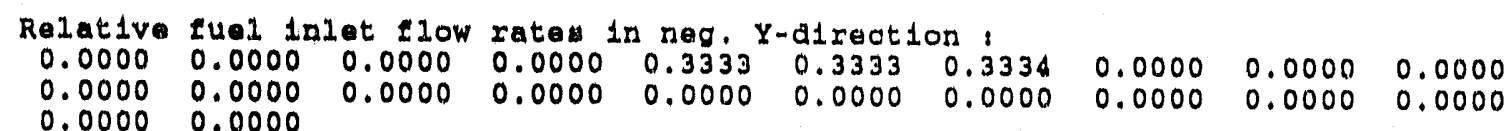

Prosa: C key to change the values Raturn to continue

Chapter 15 ,

-................

DATA FOR INITIAL VOLUME AND GURFACE ZONE TEMPERATURES

Preas P key to by-pass this chapter

$R$ key to save 11.10 and oxit 2 DINPT

Return to prooead through this ohapter

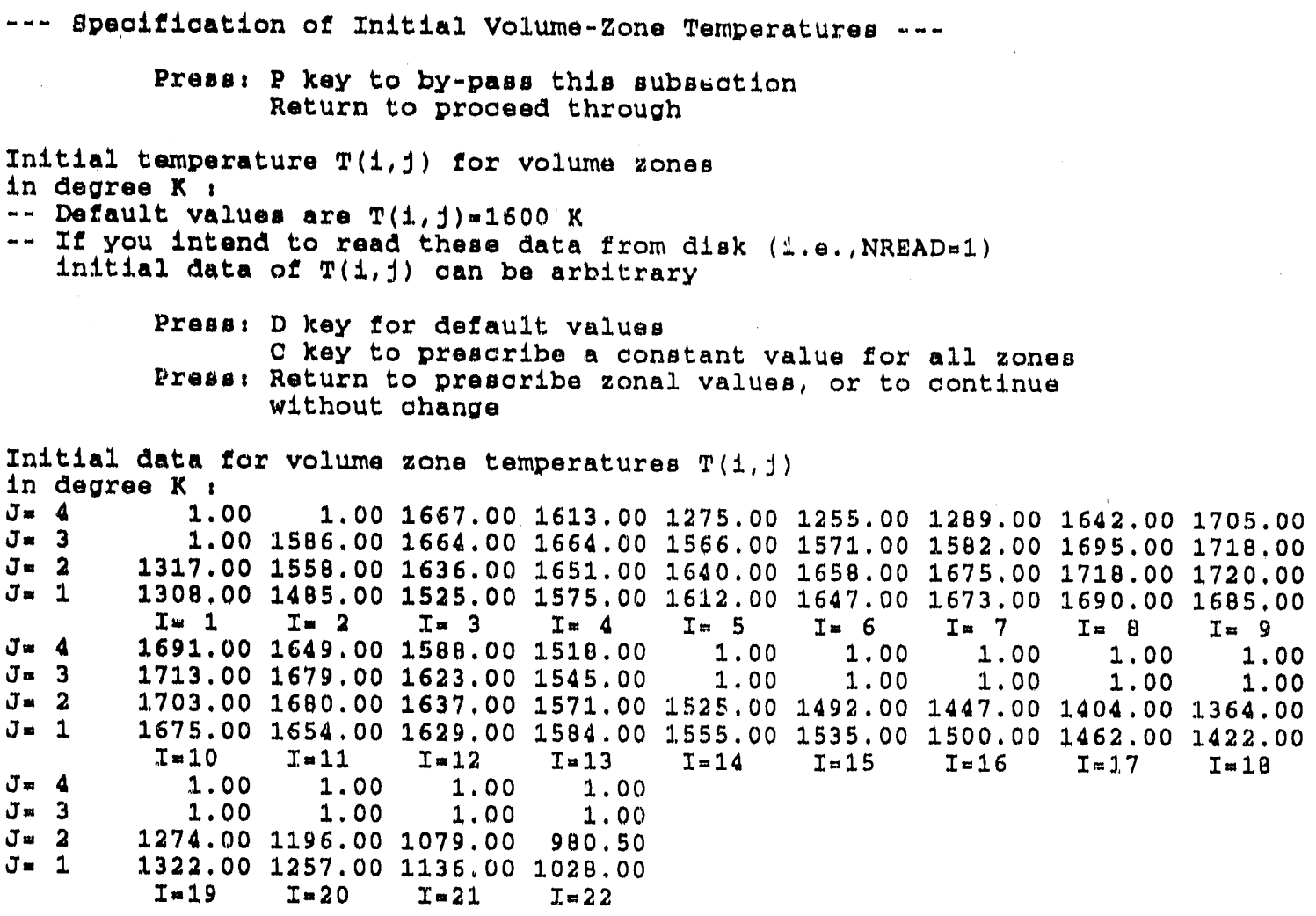

To change the inftal data column by column

preas C key, eloe preas Return

-.. Spealidation of Intt1al surface-Zone Temperatures -..

Press: P key to by-pass this subsection Return to proceed through

Int.tal temperature $T W(1, J)$ for ourface zones

in degree $\mathrm{K}$ :

-- Default values are $T W(*, *)=1200$. K, exoept at outlets,

where you have to specify equivalent surface temperatures

Press: D key for default valuea

C key to prescribe a constant value for all zonea

presa: Return to prescribe zonal values, or to continue 
without ohange

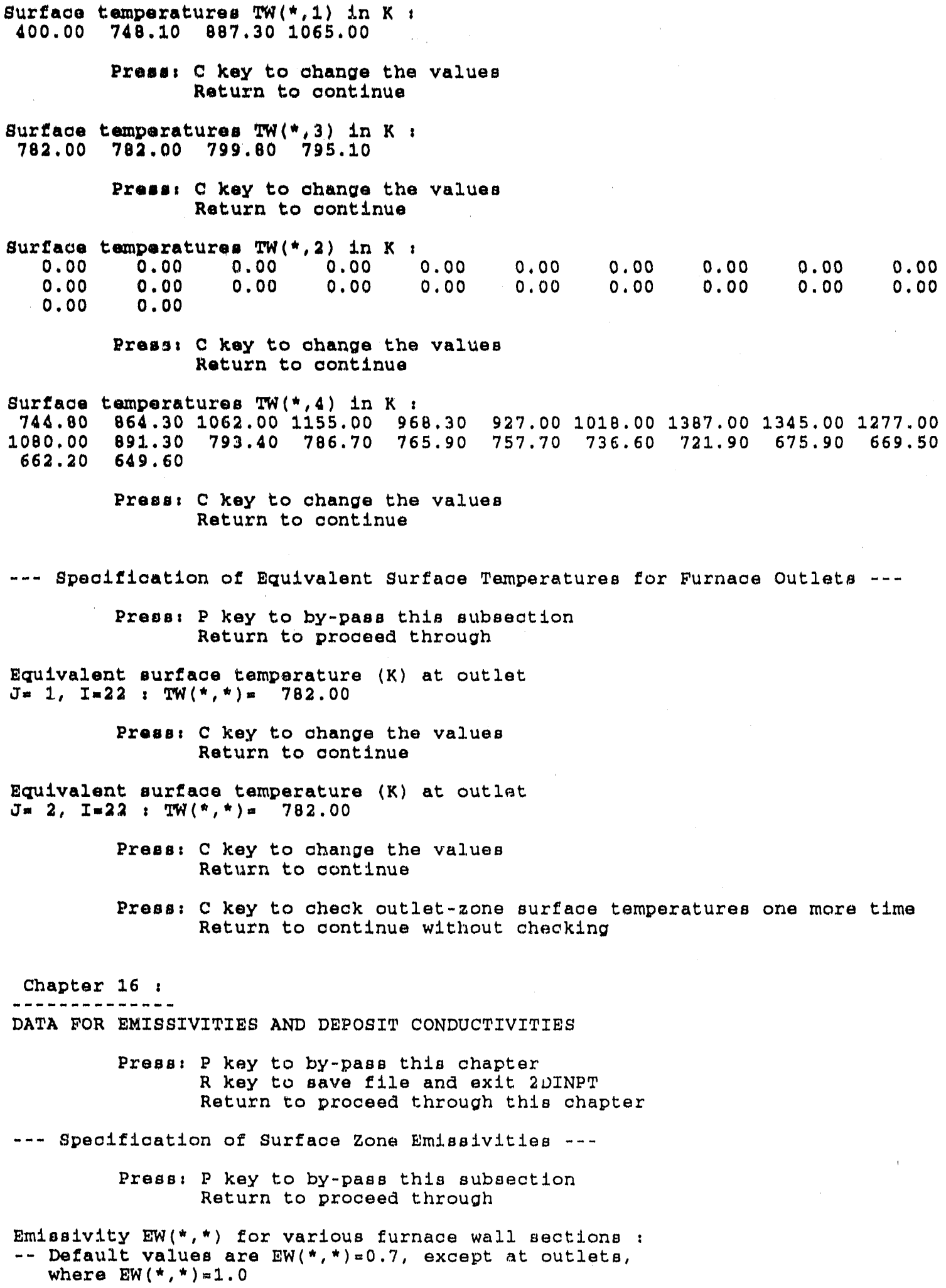




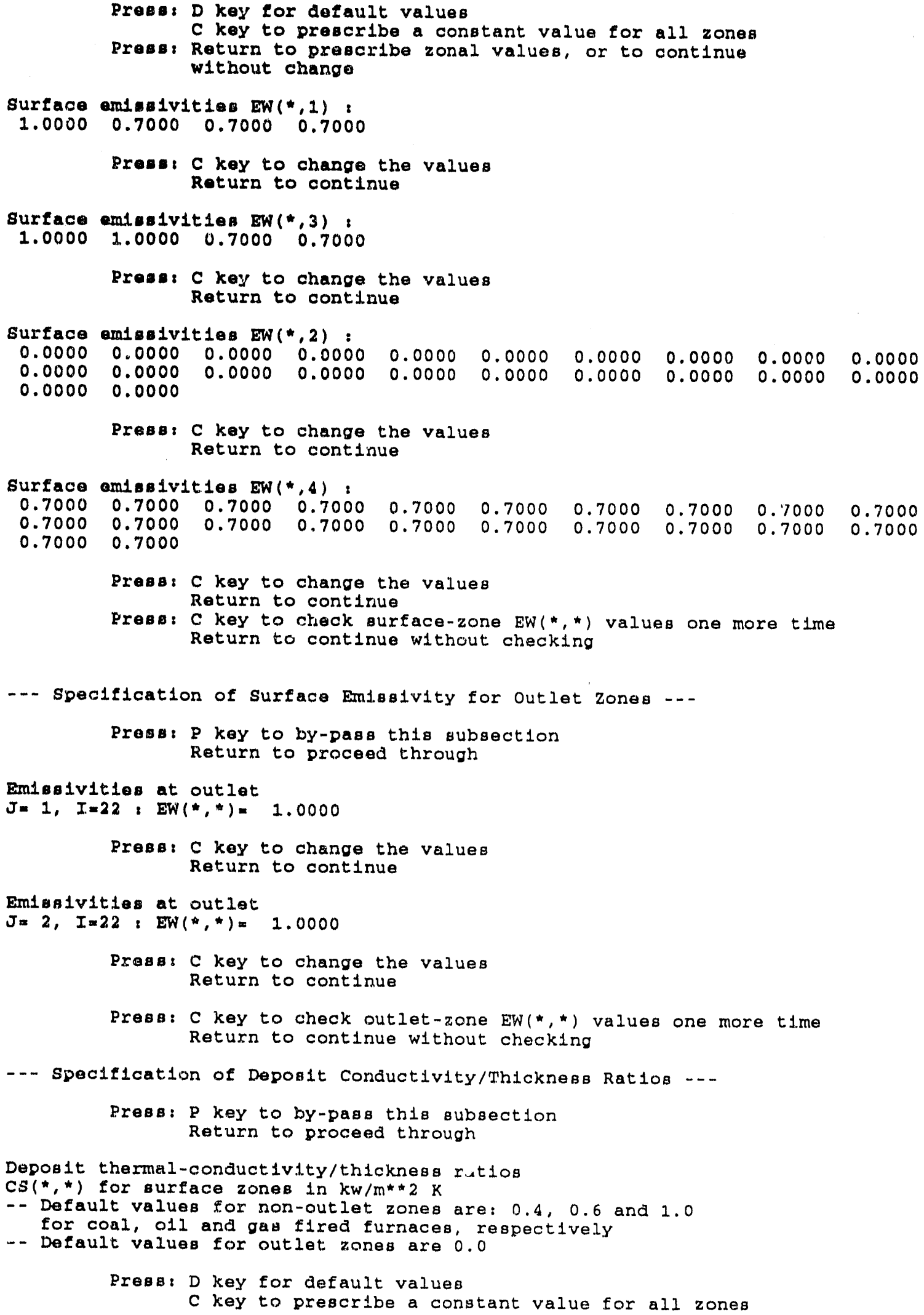

Press: C key to change the values Return to contiriue

Prese: C key to check ourface-zone EW(*, *) values one more time Return to continue without checking 
Preas: Return to presorlbe zonal values, or to continue without change

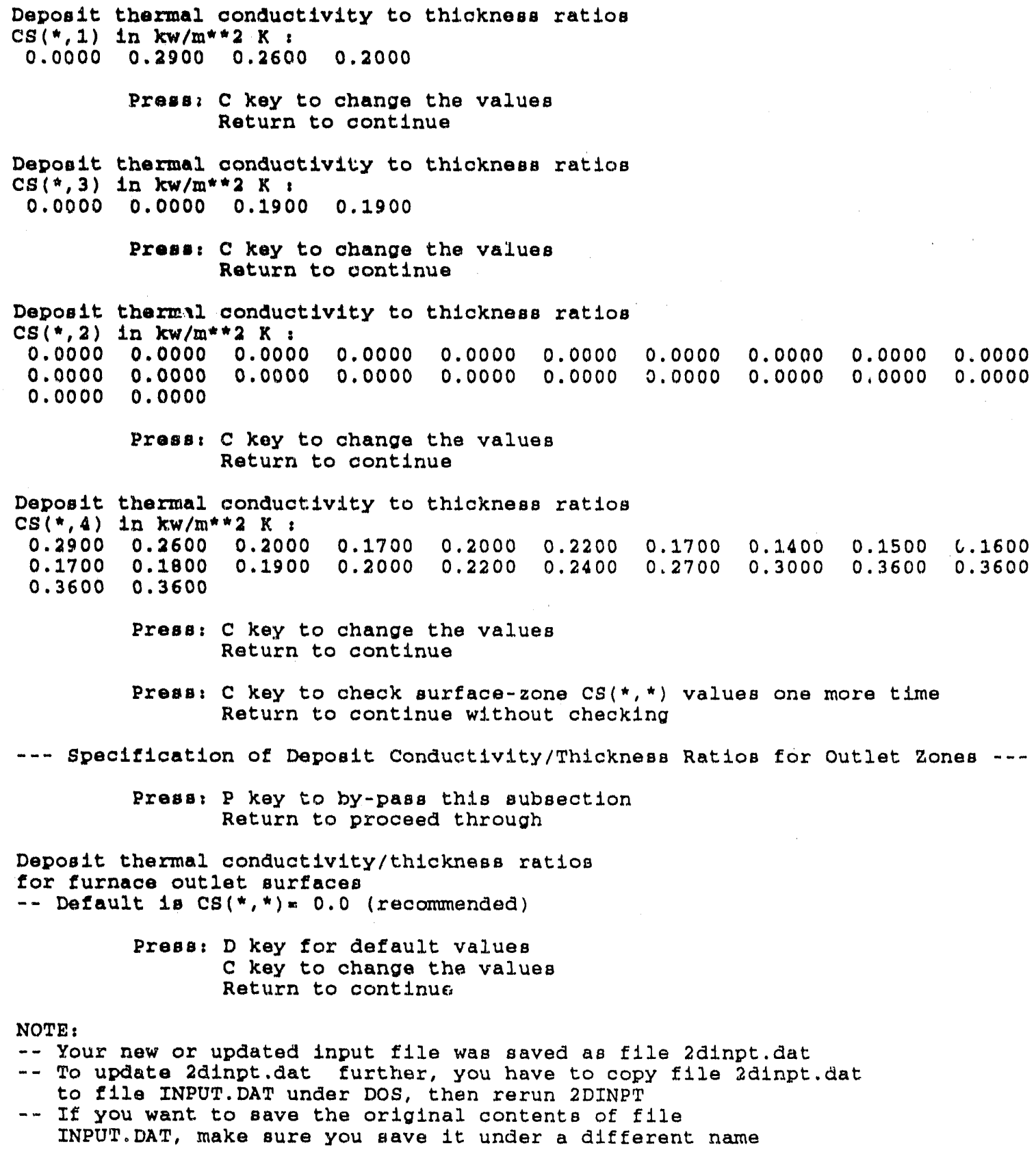




\section{APPENDIX B. SAMPLE OUTPUT FROM THE FURNACE CODE}

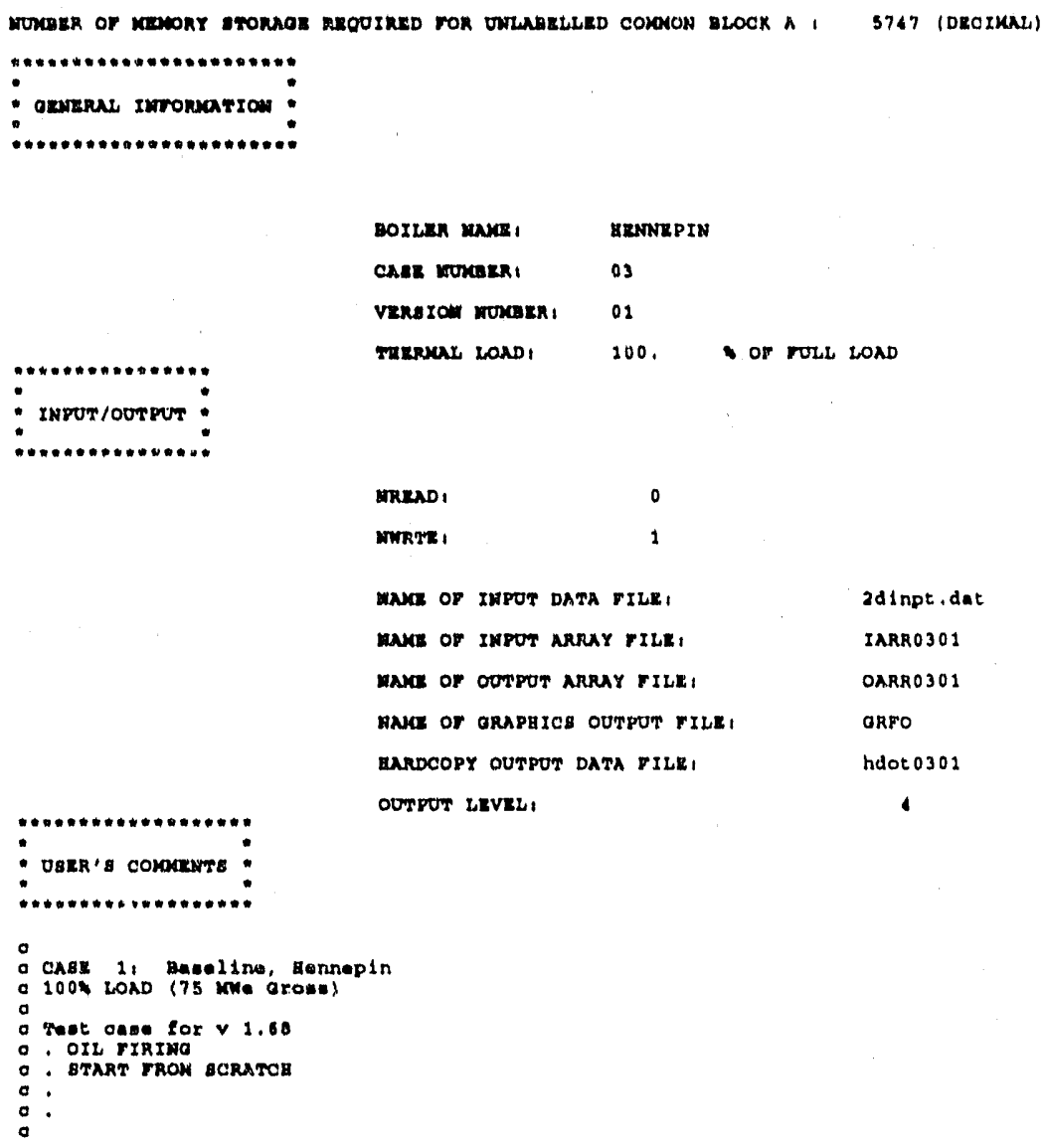




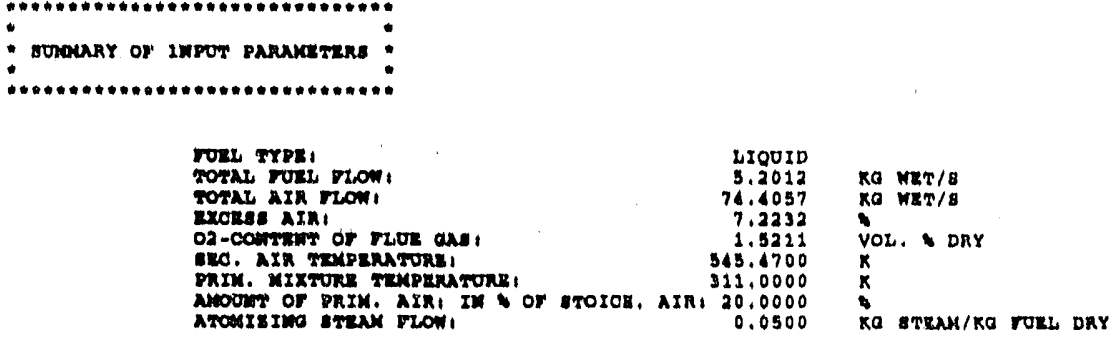

rophe proprenty.

\begin{tabular}{|c|c|c|c|}
\hline phoxtraty: & $\begin{array}{l}\text { orix } \\
\text { YoL } \\
\text { MOI } \\
\text { ABII }\end{array}$ & $\begin{array}{l}0.2200 \\
0.8592 \\
0.0200 \\
0.0000\end{array}$ & $\begin{array}{l}\mathrm{Ka} / \mathrm{kO} \\
\mathrm{kO} / \mathrm{ka} \\
\mathrm{Ka} / \mathrm{ka} \\
\mathrm{Ka} / \mathrm{ka}\end{array}$ \\
\hline 02, Thate: & 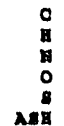 & $\begin{array}{l}0.0570 \\
0.1050 \\
0.0016 \\
0.0016 \\
0.0280 \\
0.0008\end{array}$ & 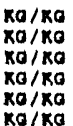 \\
\hline
\end{tabular}

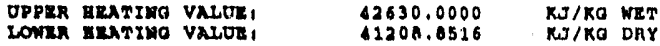

RXsONosisa :

RRBOTH OR COTIRIMO

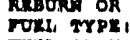

roves Tropt

ron plow:

FOR TRMPERATURE

songerst:

DORAEWT INJECTION

GONBERT TYPEI

cal: nozar Ratio

MRMUPOPOR AIR TLOM

IXTORE TMMPRATERs

OPRIMUTA IMJECTION TERPERATURE

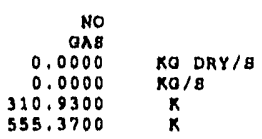

88 gapiation

CLOOD EPECTIIO ABSORPTION COETFICIENT

CLOOD BPECIYIC ABRTACE AREA

caterering

ASSORPTION EYTICIMHCY,

cCATterino urficinacy,

$\begin{array}{rl}\text { NO } & \\ \text { IYDRUTR } & \\ 0.0000 & \\ 0.0000 & K 0 / 8 \\ 0.0000 & R \sigma \\ 0.0000 & R \\ 0.0000 & K\end{array}$

YOXGRTCNL PARAMETzRB:-

\begin{tabular}{|c|c|}
\hline 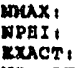 & \\
\hline $\begin{array}{l}\text { no. or } \\
\text { of or }\end{array}$ & $\begin{array}{l}\text { ITERATIONB I } \\
\text { NVERAOED I TERATIONB }\end{array}$ \\
\hline
\end{tabular}

MO, Or AVZRAazd I TERATIONB! 10

Calcolationg ar conplate combugtson

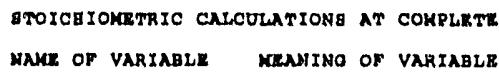

WAKR OF VARIABLI
OZMIN
AIRMIN
AIRNR
B2OFOT
BJOA2
FOTOT
DKA
DKH2O
DHTOT

MTOTCgIOMERRIO O2

Trorch Tovernic

TOTAL AIR NTMER

GOKIDITY OF TOE:

GONIDITY OF AIR

FLON RATZ OT DRY FURL

rLOW RATE OF DAY AIR

TOTAL INPOT MASS FLON RATE

TOTAL INPOT MASB FLON RATR

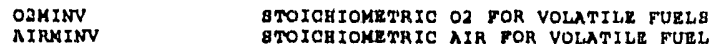

MABS FLOW RATE OF BURNER FUE

MABS FLOH RATE OF BURNER FUEL

MAgS FLOH RATE OF REBURN FUE

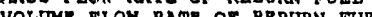

YOLOTE TLON RATE OF REBURN FUR

KASS FLOM RATE OF TOTAY. OR BRC. AIR

HABS TLOM RATE OF TOTAL OR BEC. AIR

VOLOWE FLOW RATR OF TOTAL OR BEC. AIR

VOLURE FLOH RATE OF TOTAL OR BRC. AIR

VOLUMR FHOW RATE OF COKBUSTION OASR

VOLOKR FLOH RATT OF COKBOBTION OA
HET CAL, VALUR OF BURNER FURL

GROBS CAL. VALUE OF BURNRR FUEI

MET CAL. VALUZ OF RRBQRN FOEL

GROSG CAL, VALUE OF REBURN FURT

$\begin{array}{rl}13.6364 & 1 /\left(\left(K_{0} / M * * 3\right) H\right) \\ 565.4500 & N * 02 / K O \\ N O O & \\ 0.1000 & \\ 0.0000 & \end{array}$

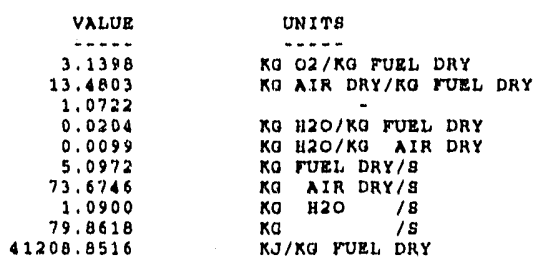

KO O2/KO FURL DRY

RO AIR DRY/KO FURL DRY

KO FIIEL DRY/S

KO YURL HRT/

KO FURL DRY/

KO FOEL HET/

M3N OAS DRY/S
M3N OAS HET/S

RO AIR DRY/B

XO AIR WET/S

M3N AIR DRY/g

H3N AIR WET/S

M3N OAS DHY/S

K3N OARE WET/Q

KJTKO FUEL, DRY

RJ/KO REBORN-PURL DRY

41200.0516

1.0000 


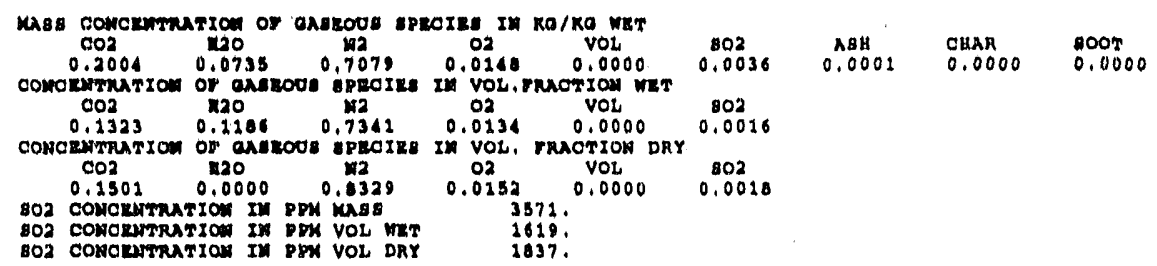

GEAT CAPACITY Or CONODOTION APECIRE (KJ/KO-K)

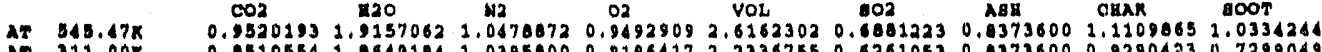
AF 311.00R 0.0510551 .08491841 .03950000 .91864172 .23367550 .02610530 .03736000 .929042300 .7299049

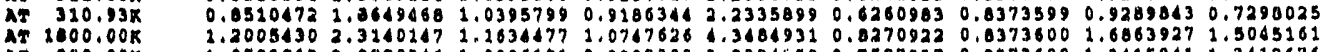

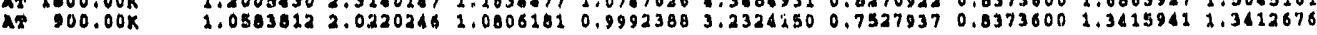

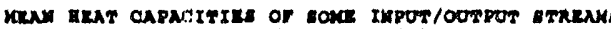

\begin{tabular}{|c|c|c|}
\hline $\begin{array}{c}\text { AIR } \\
\text { AIR } \\
\text { rugE oAs } \\
\text { rugE oAd }\end{array}$ & $\begin{array}{r}311.00 \\
315.47 \\
100.00 \\
1000.00\end{array}$ & $\begin{array}{l}1.0197977 \\
1.0336750 \\
2.1429865 \\
1.2529379\end{array}$ \\
\hline
\end{tabular}

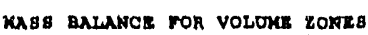

YR I

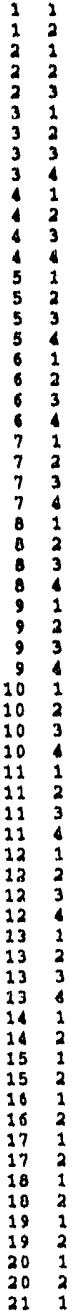

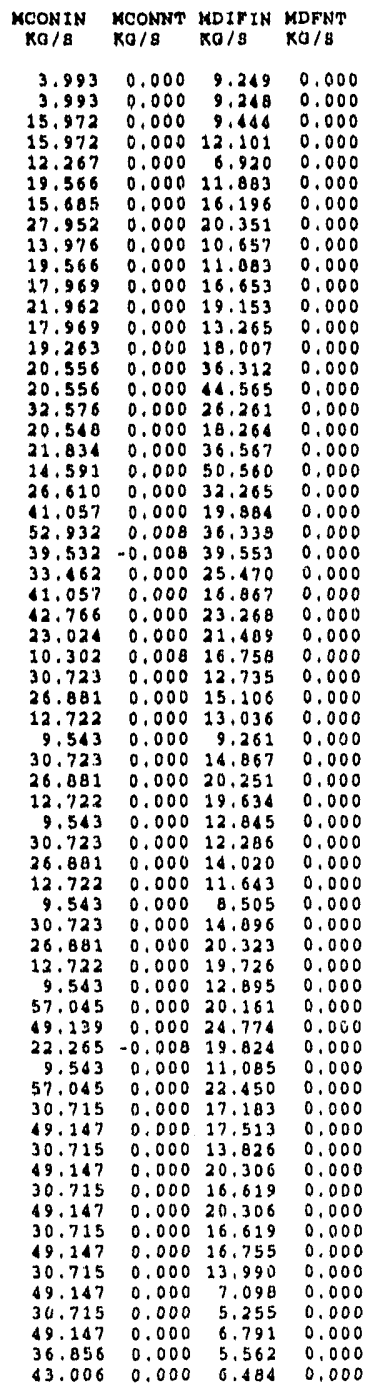

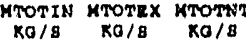

$13.242 \quad 13.242 \quad 0.000$

$\begin{array}{lll}13.261 & 13.241 & 0.000 \\ 25.417 & 25.417 & 0.000\end{array}$ $\begin{array}{lll}25.417 & 25.417 & 0.000 \\ 28.073 & 28.073 & 0.000\end{array}$ $\begin{array}{lll}28.073 & 28.073 & 0.000 \\ 19.187 & 19.187 & 0.000\end{array}$ 31.44931 .1490 .000 $31.80131 .881 \quad 0.000$ $60.30380 .303 \quad 0.000$ $31.46931 .449 \quad 0.000$ 34.62236 .6220 .000 $41.115 \quad 11.115 \quad 0.000$ $31.23431 .234 \quad 0.000$ 56.00850 .0600 .000 65.12265 .12200 .000 $50.83658 .036 \quad 0.000$ $38.813 \quad 38.813 \quad 0.000$ $50.40258 .402 \quad 0.000$ $65.15165 .151 \quad 0.000$ 58.87458 .0760 .000 60.94150 .9410 .000 $79.08479 .076-0.008$ 58.03250 .9320 .000 57.92457 .9240 .000 66.03466 .0340 .000 $44.013 \quad 14.513 \quad 0.000$ $27.06027 .068 \quad 0.008$ $3.458 \quad 43.458 \quad 0.000$
0.7580 .000 $\begin{array}{llll}11.988 & 11.988 & 0.000\end{array}$ 25.75825 .7580 .000 15. $590 \quad 15.590 \quad 0.000$ 17.13347 .1330 .000 $32,356 \quad 32,356 \quad 0.000$ $\begin{array}{lll}22.38922 .389 & 0.000\end{array}$ $\$ 3.008 \$ 3.008 \quad 0.000$ \begin{tabular}{l}
$0.902 \quad 0.902 \quad 0.000$ \\
\hline
\end{tabular} $24.36524 .365 \quad 0.000$ $18.048 \quad 10.048 \quad 0.000$ 15.048 10.0480 .000 32.44832 .4480 .000 $32.438 \quad 22.438 \quad 0.000$ $77.206 \quad 77.206 \quad 0.000$ $73.91373 .9 .13 \quad 0.000$

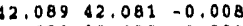

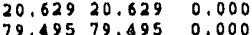
79.6957 .6980 .000 68.68006 .6500 .000 44.54184 .5410 .000 $69.453 \quad 69.453 \quad 0.000$ $47.33447 .334 \quad 0.000$ $69.45369 .453 \quad 0.000$ 6.33487 .3340 .000

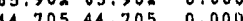
$4.705 \quad 56.2450 .000$ $35.96935 .969 \quad 0.000$ $\begin{array}{lll}55.938 & 55.938 & 0.000\end{array}$ $\begin{array}{rrr}42.418 & 12.418 & 0.000 \\ 49.489 & 49.489 & 0.000\end{array}$ 


\begin{tabular}{|c|c|c|c|c|c|c|c|c|}
\hline $\begin{array}{l}21 \\
23 \\
22\end{array}$ & $\begin{array}{l}2 \\
2 \\
3\end{array}$ & $\begin{array}{l}36.056 \\
13.008 \\
39.931\end{array}$ & $\begin{array}{l}0.000 \\
0.000 \\
0.000\end{array}$ & $\begin{array}{l}3.869 \\
3.242 \\
2.934\end{array}$ & $\begin{array}{l}0.000 \\
0.000 \\
0.000\end{array}$ & $\begin{array}{l}42.725 \\
46.247 \\
42.865\end{array}$ & $\begin{array}{l}42,725 \\
46,247 \\
12,065\end{array}$ & $\begin{array}{l}0.000 \\
0.000 \\
0.000\end{array}$ \\
\hline LODTNO & 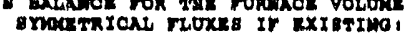 & 1860.05 & 0.00 & 2136,11 & 0.00 & 3016.96 & 3016.96 & 0.00 \\
\hline
\end{tabular}

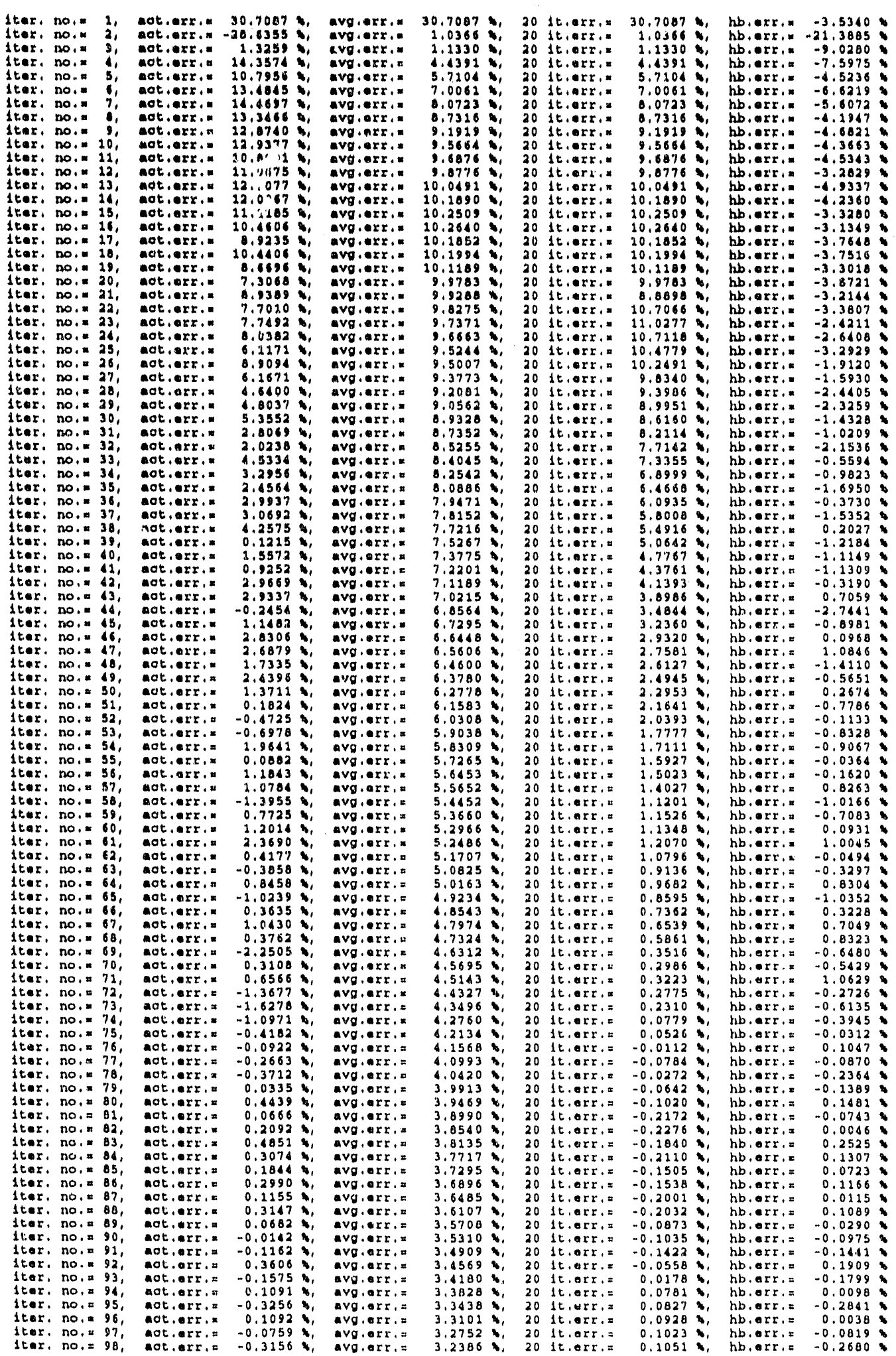




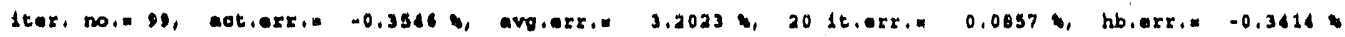

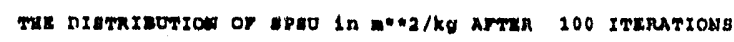

\begin{tabular}{|c|c|c|c|c|c|c|c|c|c|c|}
\hline \multirow[t]{2}{*}{$\begin{array}{ll}J_{n} & d \\
J_{n} & 3 \\
J_{n} & 2 \\
J_{n} & 1\end{array}$} & $\begin{array}{l}0.0008-01 \\
0.0008-01 \\
3.0608+02 \\
1.0058+02\end{array}$ & $\begin{array}{r}0.0008-02 \\
3.6578+02 \\
3.7968+02 \\
3.9208+02\end{array}$ & $\begin{array}{l}3.3118+02 \\
3.4028+02 \\
3.7068+02 \\
3.3908+02\end{array}$ & $\begin{array}{l}2.835 x+02 \\
3.1352+02 \\
3,7322+02 \\
1.1002+02\end{array}$ & $\begin{array}{l}2.347 z+02 \\
2.710 z+02 \\
3.363 z+02 \\
1.013 z+02\end{array}$ & $\begin{array}{l}3.325 \mathrm{z}+02 \\
2.653 \mathrm{E}+02 \\
3.209 \mathrm{E}+02 \\
3.842 \mathrm{z}+02\end{array}$ & $\begin{array}{l}2,360 z+02 \\
2,579 R+02 \\
2,911 \mathrm{z}+02 \\
3,101 \mathrm{0}+02\end{array}$ & $\begin{array}{l}3,595 R+02 \\
3,578 z+02 \\
3,517 R+02 \\
3,824 z+02\end{array}$ & $\begin{array}{l}1.079 z+02 \\
4.000 z+02 \\
3.066 z+02 \\
4.0628+02\end{array}$ & $\begin{array}{l}4.651 z+02 \\
1.3092+02 \\
4.3308+02 \\
4.3948+02\end{array}$ \\
\hline & In 1 & $x=2$ & $I=3$ & $I=1$ & $I=5$ & $x=6$ & $x=7$ & IN 0 & I. 9 & $I=10$ \\
\hline \multirow[t]{2}{*}{$\begin{array}{ll}J= & 1 \\
J= & 3 \\
J= & 2 \\
J= & 1\end{array}$} & $\begin{array}{r}1.031 z+02 \\
1.704 z+02 \\
1.513 z+02 \\
4.523 z+02\end{array}$ & $\begin{array}{r}8.1058+02 \\
4.9968+02 \\
1.0182+02 \\
1.7678+02\end{array}$ & $\begin{array}{l}5.2938+02 \\
5.1368+02 \\
5.0538+02 \\
1.906 k+02\end{array}$ & $\begin{array}{l}0.0008-02 \\
0.0002-01 \\
5.1728002 \\
5.0632+02\end{array}$ & $\begin{array}{l}0.000 z-01 \\
0.0000-01 \\
5.1918+02 \\
5.100 z+02\end{array}$ & $\begin{array}{l}0.000 z-01 \\
0.000 z-01 \\
5.230 z+02 \\
5.174 z+02\end{array}$ & $\begin{array}{l}0.000 E-01 \\
0.000 E-01 \\
5.254 E+02 \\
5.220 R+02\end{array}$ & 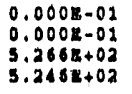 & $\begin{array}{l}0.000 x-01 \\
0.000 \Omega-01 \\
5.2672 \times+02 \\
5.2512+02\end{array}$ & $\begin{array}{l}0,0008-01 \\
0.0008-01 \\
5,2672+02 \\
3.2538+02\end{array}$ \\
\hline & $x=11$ & $x=12$ & $I=13$ & $I=14$ & $x=15$ & $I=16$ & $I=17$ & $\operatorname{Im} 10$ & $x=19$ & $1=20$ \\
\hline
\end{tabular}

Tin $0.000 \times-01 \quad 0.000 x-01$

In $330.0002-01 \quad 0.0002-02$

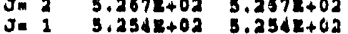

$I=21 \quad I=22$

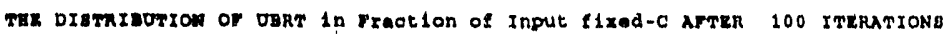

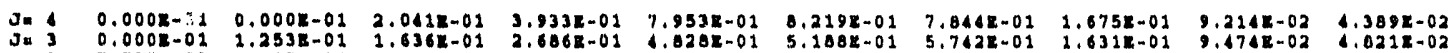

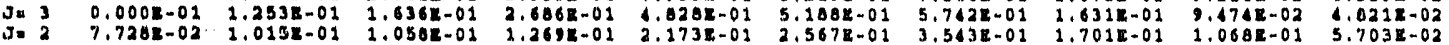

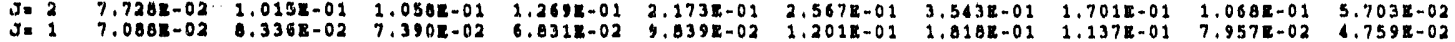
I. 1
$I=2$
I. 3 I.
$I=5$
I. 6
II $?$
IE $\theta$
$I \approx 9$
I 10

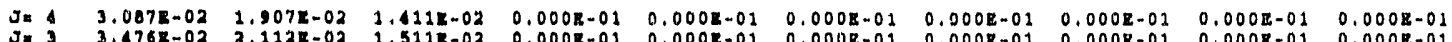

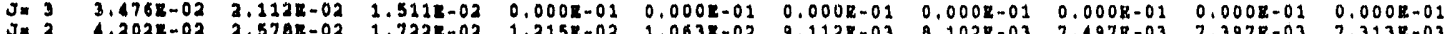

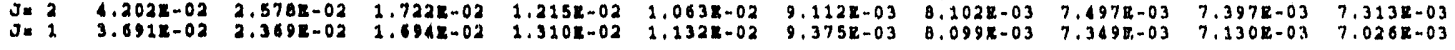
$I=11 \quad I=12 \quad I=13 \quad I=14 \quad I=15 \quad I=16 \quad I=17 \quad I=18 \quad I=19 \quad I=20$

$J=4 \quad 0.000 \mathrm{z}-01 \quad 0.000 \mathrm{x}-02$

Jat $30,0002-01 \quad 0,000 \mathrm{R}-01$

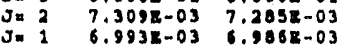

$I=21 \quad I=22$

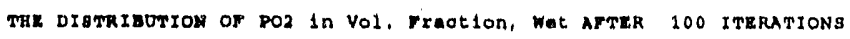

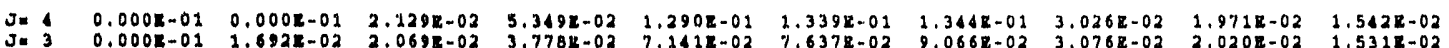

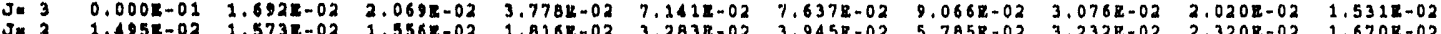

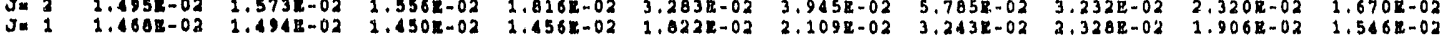
$I=1$ I. 2 In $3 \quad I=4 \quad I=5 \quad I=6 \quad I=7 \quad I=8 \quad I=9 \quad I=10$

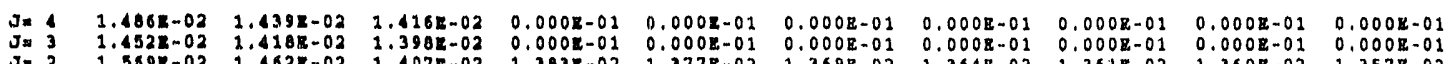

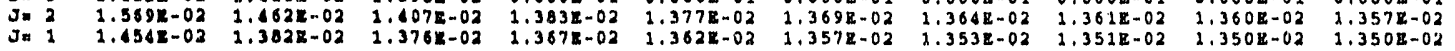
$I=11 \quad I=12 \quad I=13 \quad I=16 \quad I=15 \quad I=16 \quad I=17 \quad I=18 \quad I=19 \quad I=20 \quad$

$\begin{array}{lll}J=1 & 0.0002-01 & 0.000 R-01 \\ J=3 & 0.000 \mathrm{R}-01 & 0.000 \mathrm{R}-01\end{array}$

$\begin{array}{lll}J=2 & 1.3572-02 & 1.358 \mathrm{R}-02 \\ J=1 & 1.349 \mathrm{R}-02 & 1.349 \mathrm{R}-02\end{array}$

$$
I=21 \quad I=22
$$

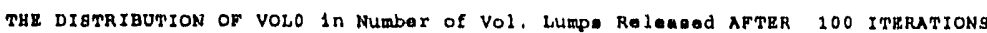

$J=1 \quad 0.000 \mathrm{R}-01 \quad 0.000 \mathrm{z}-01 \quad 0.000 \mathrm{R}-01 \quad 3.300 \mathrm{R}+01 \quad 3.306 \mathrm{R}+03 \quad 3.310 \mathrm{R}+03 \quad 3.309 \mathrm{~g}+03 \quad 3.000 \mathrm{R}+00 \quad 0.000 \mathrm{R}-01 \quad 0.000 \mathrm{R}-01$

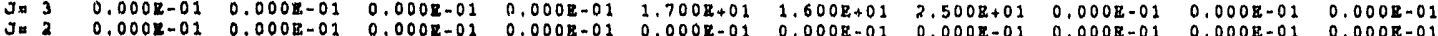

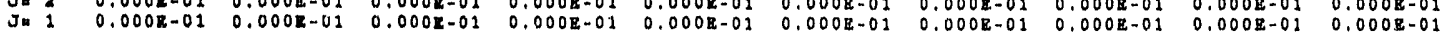
In 1
$I=2$
$I=3$
$I=4 \quad I=5$
$I=0$
$1=7$
$I=8$
$I=9 \quad I=10$

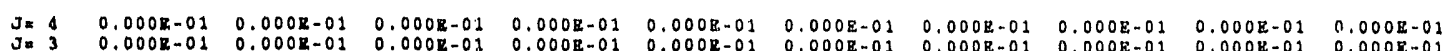

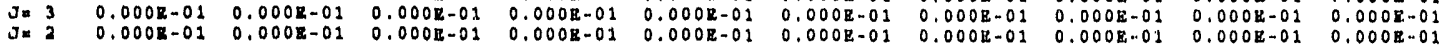

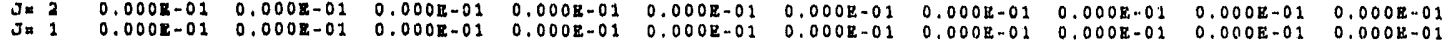

$$
I=11 \quad I=12 \quad I=13 \quad I=14 \quad I=15 \quad I=16 \quad I=17 \quad I=18 \quad I=19 \quad I=20
$$

Jn $\quad 0.000 \mathrm{R}-01 \quad 0.000 \mathrm{R}-01$

$\begin{array}{llll}J=3 & 0.000 \mathrm{R}-01 & 0.000 \mathrm{R}-01\end{array}$

$\begin{array}{lll}J=2 & 0.0002-01 & 0.000 R-01 \\ J=1 & 0.000 R-01 & 0.000 R-01\end{array}$

$I=22 \quad I=22$ 


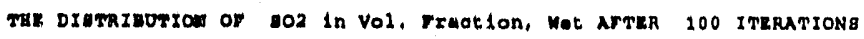

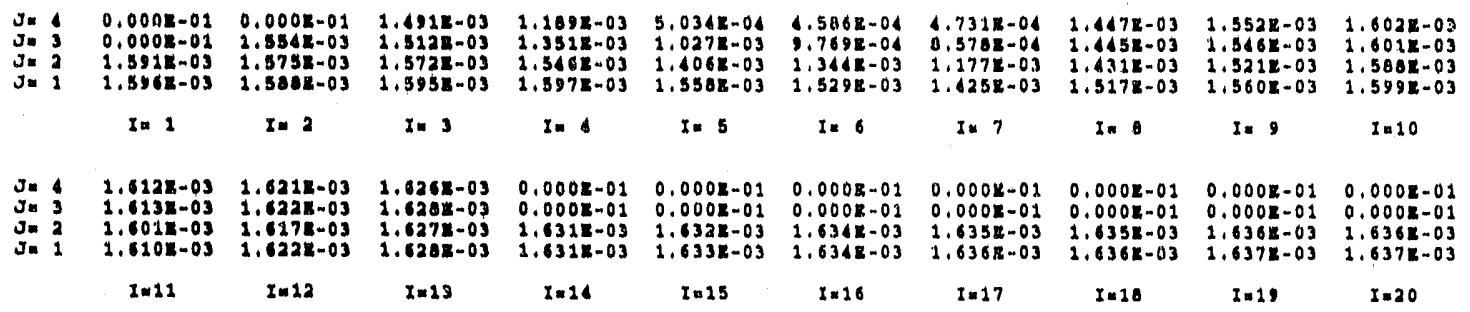

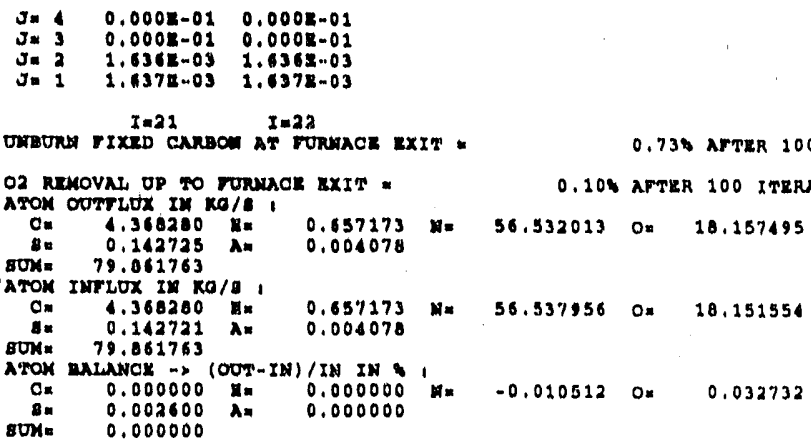

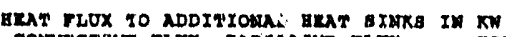

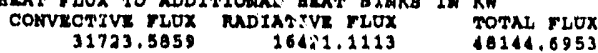

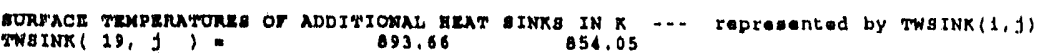

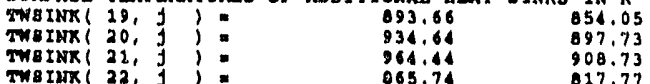

MEAN FORNACE EXIT TEMPERATURE " $1109.87 \mathrm{X}$ AFTER 100 ITRRATYON

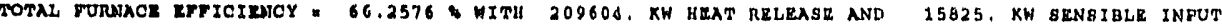

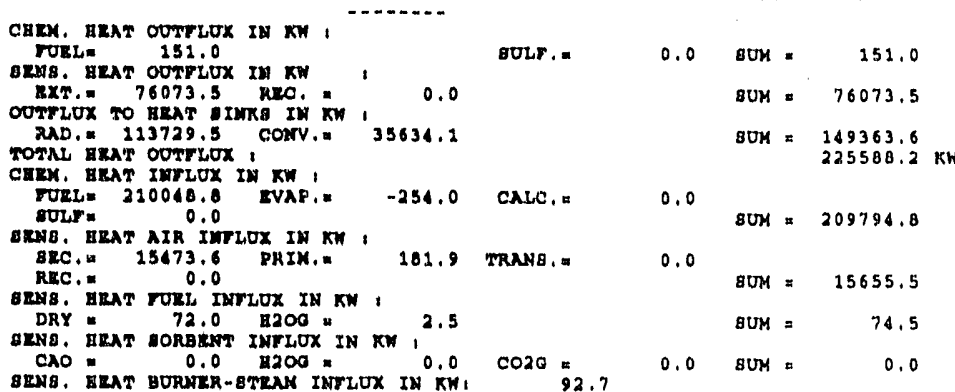

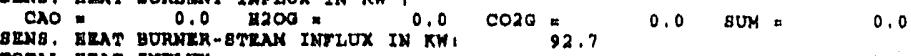

TOTAL MEAT IMTrLuX 1

$225617.5 \mathrm{KW}$

GRAT BALANCR $\rightarrow$ OOT - IN

THZ DIATRIBUTION OF T In $X$ AFTER 100 ITERATIONS

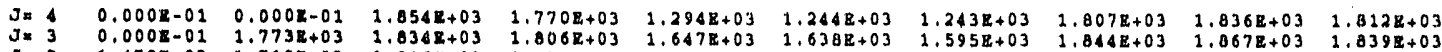

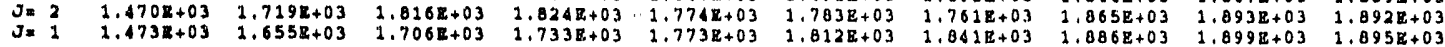

$$
I=1 \quad I=2 \quad I=3 \quad I=4 \quad I=5 \quad I=6 \quad I=7 \quad I=8 \quad I=9 \quad I=10
$$

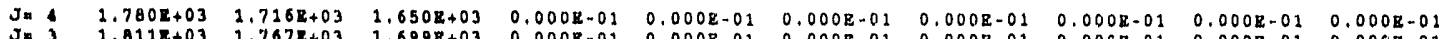

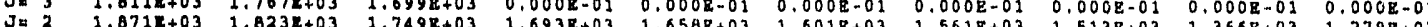

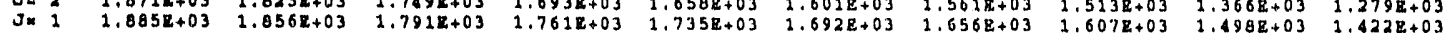
$I=12 \quad I=12 \quad I=13 \quad I=14 \quad I=15 \quad I=16 \quad I=17 \quad I=18 \quad I=19 \quad I=20 \quad$

Jut $0.000 R-01 \quad 0.0002-01$

$J=3 \quad 0.000 \mathrm{R}-01 \quad 0.000 \mathrm{R}-01$

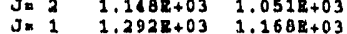

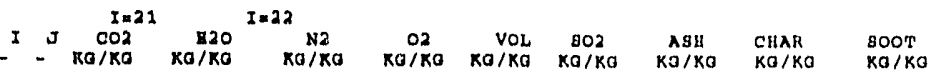




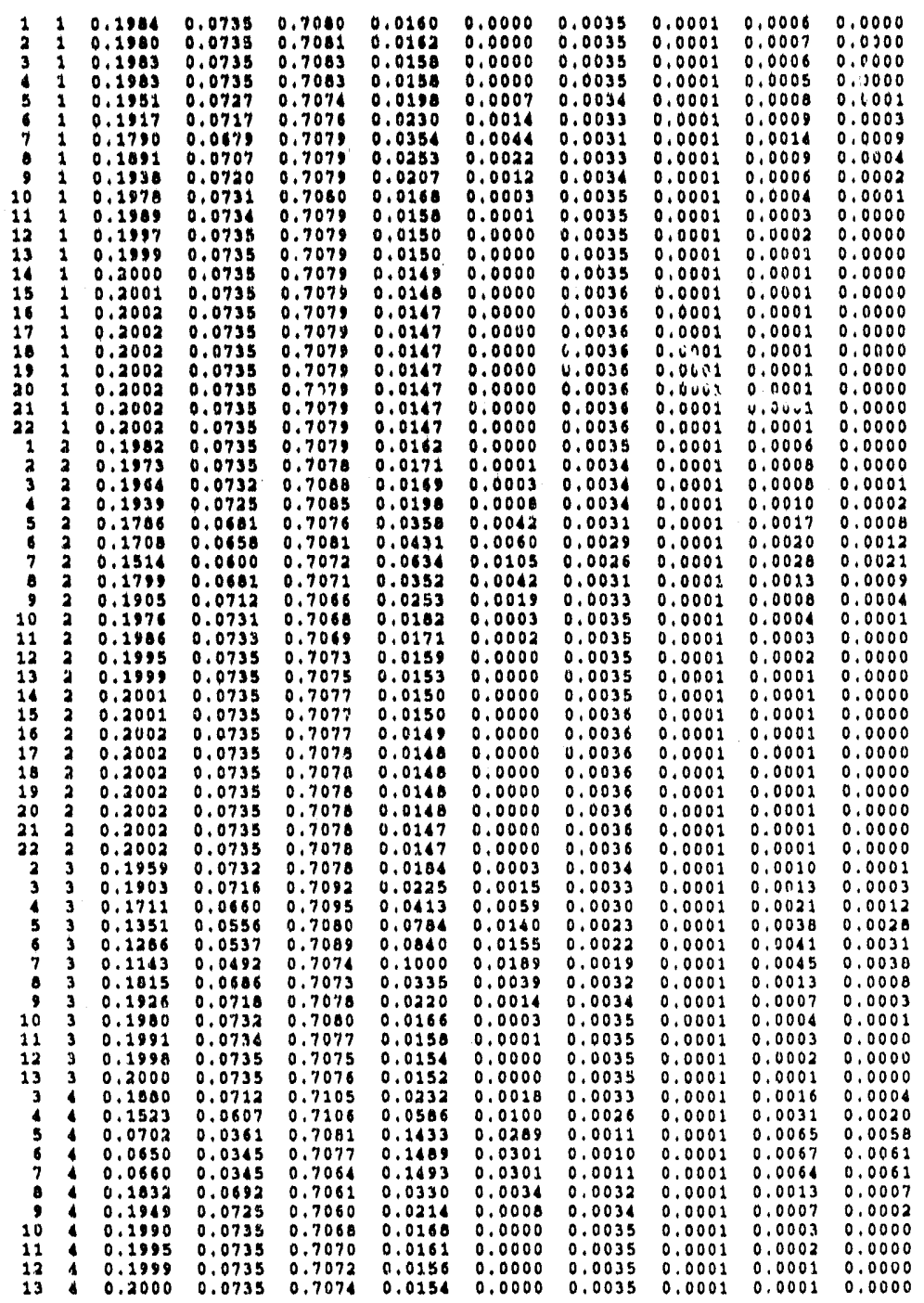

THE DIBTRIBUTION OF QO In KM/m*"3 AFTER 100 ITEKATIONS

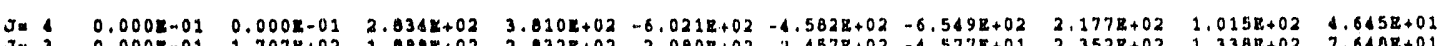

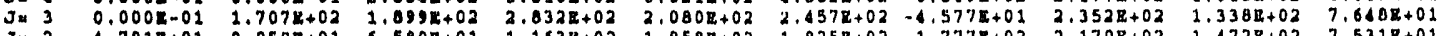

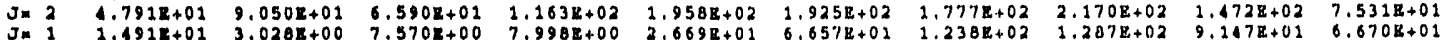
$I=1$
I. 2
$I=3$
In 4
$I=5$
$I=6$
$I=7$
$I=B$
$I=9$
$I=10$

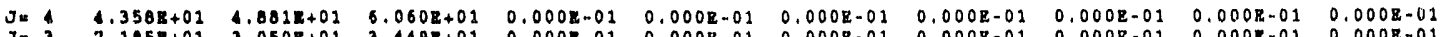

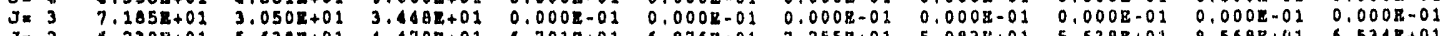

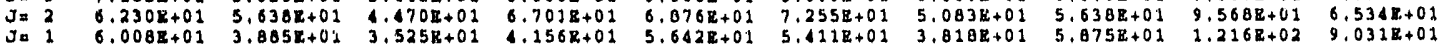
$I=11 \quad I=12 \quad I=13 \quad I=14 \quad I=15 \quad I=16 \quad I=17 \quad I=18 \quad I=19 \quad I=30$

$J=0.0008-01 \quad 0.000 \mathrm{~B}-01$

$J=3 \quad 0.000 \mathrm{R}-01 \quad 0.000 \mathrm{x}-0$

$\begin{array}{lll}J=2 & 5.285 \mathrm{z}+01 & 3.351 \mathrm{~B}+01 \\ 1 & 6.005 \mathrm{k}+01 & 6.609 \mathrm{Z}+01\end{array}$

$I=21$

$I=22$

THE DIOTRIBUTION OF TREg in woO AFTER 100 ITERATIONg

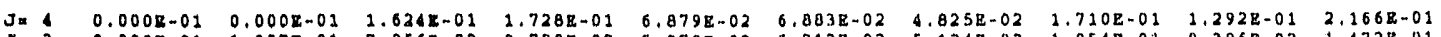

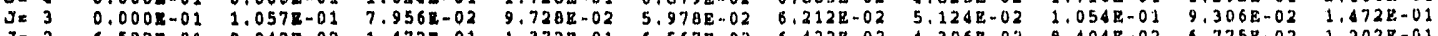

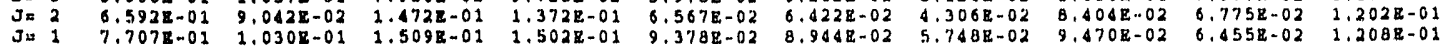
In 2
$I=2$
I. 3
$I=4$
$I=5$
$I=6$
$I=7$
$I=0$
$I=9$
$I=10$ 


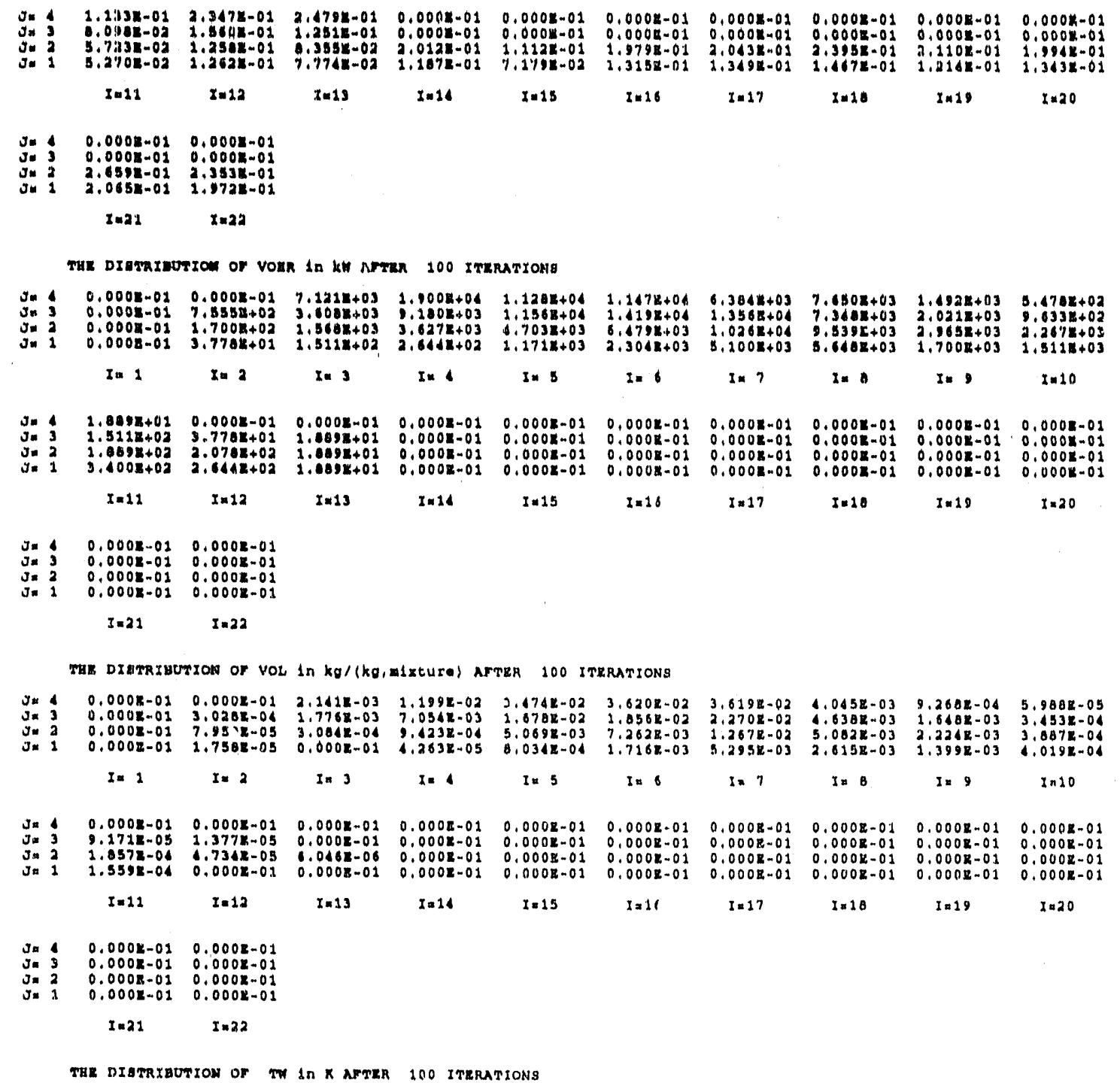


M3. 1

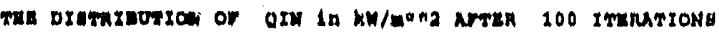

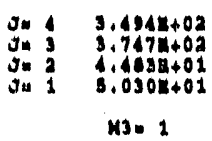

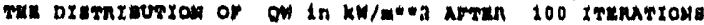

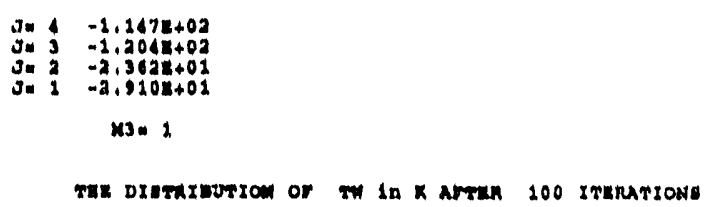

ILAT FLUXHS TO ZONAL HRAT EXCHANOERG IN KW, 


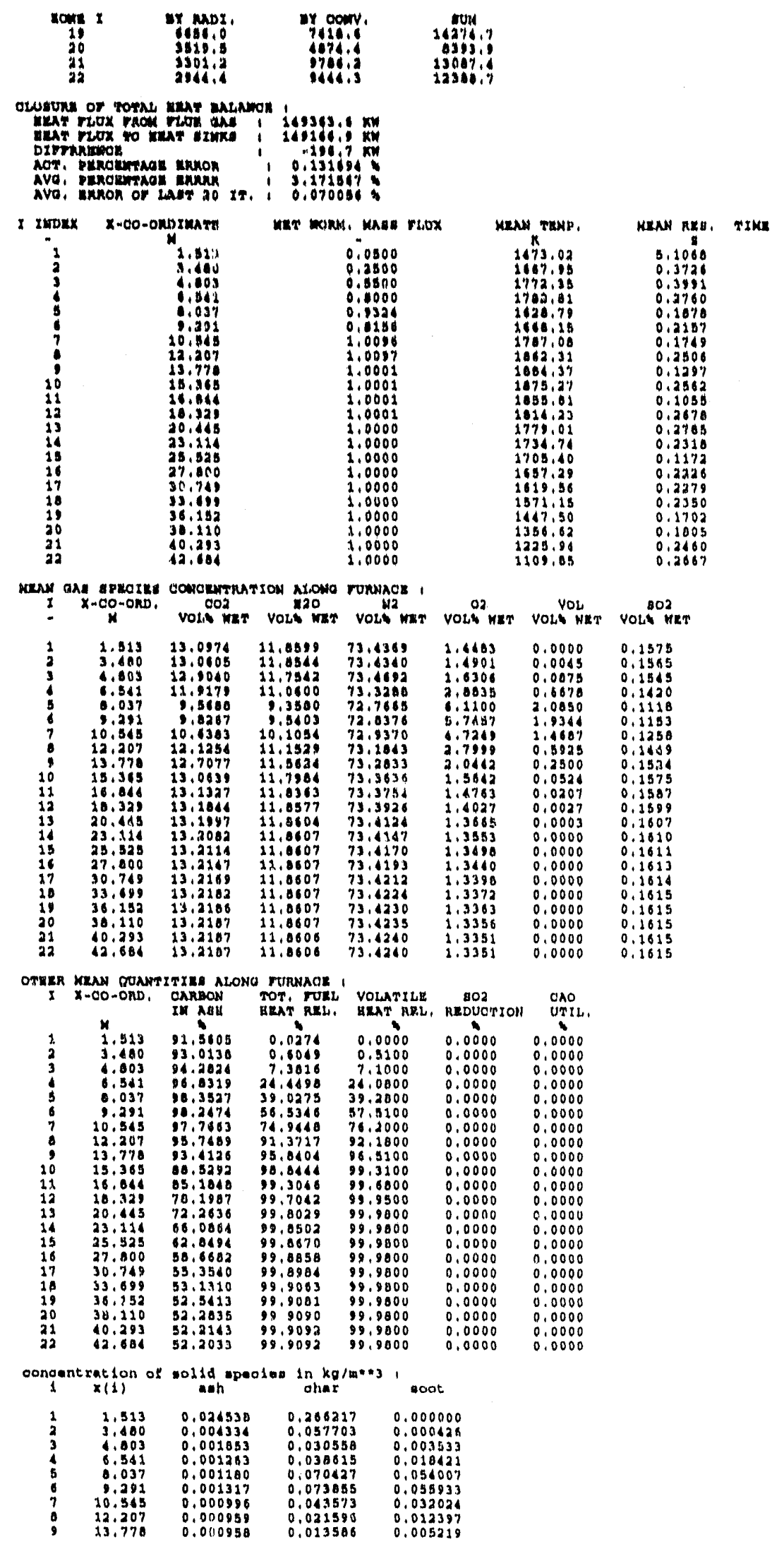


\&1, :

\begin{tabular}{|c|c|c|c|c|}
\hline 8 & 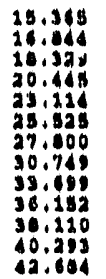 & 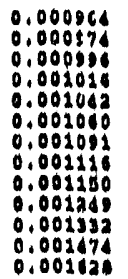 & 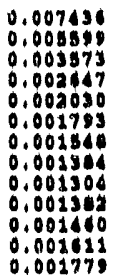 & 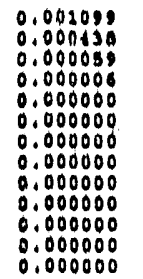 \\
\hline
\end{tabular}



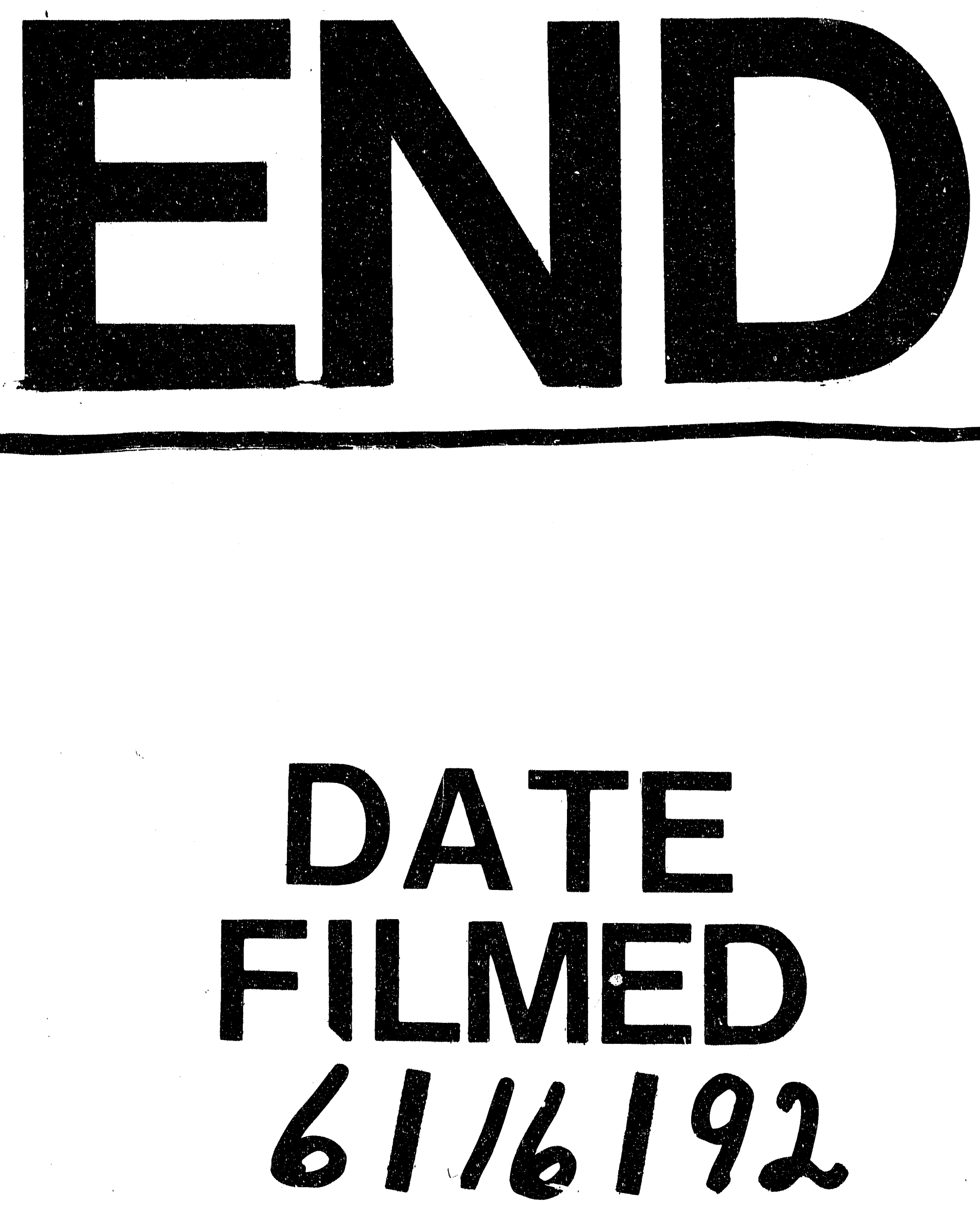

هـ 